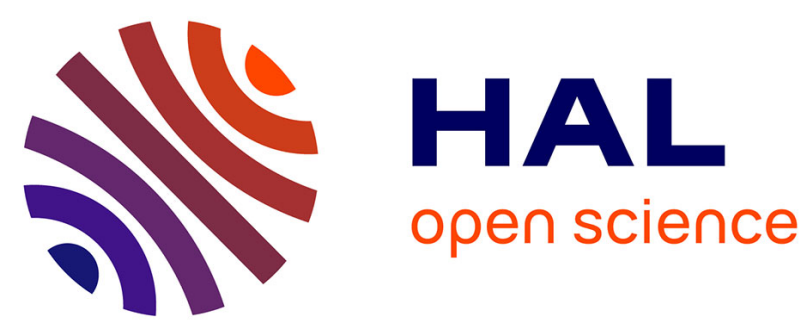

\title{
Synthesis of Adenine Dinucleosides 2',5'-Bridged by Sulfur-Containing Linkers as Bisubstrate SAM Analogues for Viral RNA 2'- O -Methyltransferases
}

Rostom Ahmed-Belkacem, Priscila Sutto Ortiz, Etienne Decroly, Jean-Jacques Vasseur, Françoise Debart

\section{- To cite this version:}

Rostom Ahmed-Belkacem, Priscila Sutto Ortiz, Etienne Decroly, Jean-Jacques Vasseur, Françoise Debart. Synthesis of Adenine Dinucleosides 2',5'-Bridged by Sulfur-Containing Linkers as Bisubstrate SAM Analogues for Viral RNA 2'- O -Methyltransferases. European Journal of Organic Chemistry, 2019, 2019 (38), 10.1002/ejoc.201901120 . hal-02992283

\section{HAL Id: hal-02992283 \\ https://hal.science/hal-02992283}

Submitted on 6 Nov 2020

HAL is a multi-disciplinary open access archive for the deposit and dissemination of scientific research documents, whether they are published or not. The documents may come from teaching and research institutions in France or abroad, or from public or private research centers.
L'archive ouverte pluridisciplinaire HAL, est destinée au dépôt et à la diffusion de documents scientifiques de niveau recherche, publiés ou non, émanant des établissements d'enseignement et de recherche français ou étrangers, des laboratoires publics ou privés. 


\title{
Synthesis of adenine dinucleosides 2',5'-bridged by sulfur-containing linkers as bisubstrate SAM analogues for viral RNA 2'-O-methyltransferases
}

\author{
Rostom Ahmed-Belkacem, ${ }^{1}$ Priscila Sutto Ortiz, ${ }^{2}$ Etienne Decroly, ${ }^{2}$ Jean-Jacques Vasseur $^{1}$ and \\ Françoise Debart ${ }^{1, *}$ \\ 1. IBMM, UMR 5247, CNRS, University of Montpellier, ENSCM, Montpellier, France \\ 2. AFMB, CNRS, Aix-Marseille University, UMR 7257, 163 avenue de Luminy, Marseille, France
}

\begin{abstract}
Viral RNA 2'-O-methyltransferases play a crucial role for luring the host cell innate antiviral response during a viral infection by catalyzing either the methylation of the 5'-end RNA cap-structure at 2'-OH of nucleoside $\mathrm{N} 1$ or by inducing internal 2'-O-methylation of adenosines within RNA sequence using $S$-adenosyl-L-methionine (SAM) as the methyl donor. Our goal is to synthetized bisubstrate SAM analogues mimicking the transition state of the 2'-O-methylation of the RNA in order to block viral 2'$O$-methyltransferases and struggle against emerging viruses. Here we designed and synthesized five dinucleosides by connecting a 5'-thioadenosine representing the SAM to the 2'-OH of another adenosine unit mimicking the RNA substrate, via various sized sulfur-containing linkers such as alkylthioether linkers, sulfoxide or sulfone derivatives, or a disulfide bond.
\end{abstract}

\section{Introduction}

Emerging RNA viruses (eg., Dengue, Zika, SARS, MERS, Ebola viruses) are important human pathogens causing substantial health and economic burden. ${ }^{[1]}$ Their spreading is, among others, linked to their rapid evolution combined with their capacity to escape antiviral response by hiding their RNA from detection by antiviral sensors or restriction factors. ${ }^{[2]}$ The viral replication/transcription complex contains enzymes essential for virus replication, which are involved in RNA synthesis (polymerase) and RNA capping. The cap structure, consisting of a guanosine linked by a 5'-5'-triphosphate bridge to the 5'-end of messenger RNAs, protects viral RNA from degradation by cellular nucleases. Particularly, our research aims at studying and targeting viral RNA Methyltransferases (MTases) which play a crucial role by catalyzing the methylation of the RNA cap-structure using $S$-adenosyl-L-methionine (SAM) as the methyl donor. Viral N7-MTase methylates the cap at the nitrogen in position $N 7$ of guanosine in order to allow RNA translation into viral proteins. ${ }^{[3]}$ The cap structure is also often methylated at the 2'$O$-position of the N1 residue (adenosine or guanosine) by 2'-O-MTase. Moreover, internal 2'-Omethylations of viral RNA have been demonstrated with Sudan ebolavirus, Dengue and Zika viruses, and HIV. ${ }^{[4]}$ These 2'-O- methylations were recently evidenced as self-markers, hiding viral RNA from detection by RIG-like receptors ${ }^{[2 c, 5]}$ and limiting the restriction of viral replication by IFIT1/3 molecules. ${ }^{[6]}$ It is now currently admitted that these key enzymes are potent antiviral targets, as their inhibition will both unmask the viral RNA to the innate immunity and limit the virus replication. Smallmolecule RNA MTase inhibitors (Sinefungin, 5'-methylthioadenosine (MTA), SAM or S-adenosyl-Lhomocysteine (SAH) have already been described but these SAM analogs show inadequate selectivity due to the high homology of SAM binding domain of the different RNA MTases. ${ }^{[7]}$ To overcome this lack of selectivity, we propose to develop another approach with bisubstrate nucleosidic analogues as 2'-O-MTase inhibitors by mimicking the transition state of the 2'-O-methylation of the RNA cap structure (Scheme 1). ${ }^{[7]}$ 

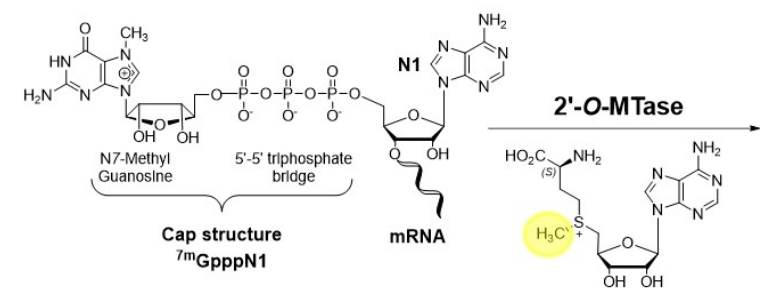

SAM

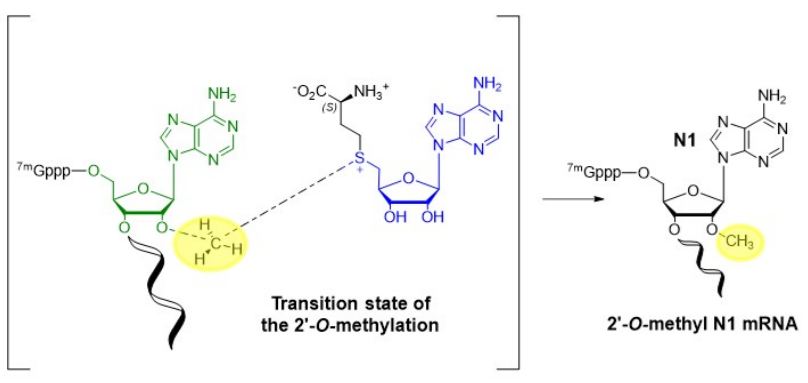

Scheme 1. The 2'-O-methyltransferase reaction on the cap structure of a mRNA with its transition state intermediate

These analogues consist of a SAM analogue without the amino acid side chain, covalently bound to the 2'-OH of an adenosine unit via various sized linkers containing one or two sulfur atoms. In this bisubstrate approach, the SAM analogue has been designed to accommodate the SAM binding pocket of the 2'-O-MTase and the adenosine unit represents the 5'-end nucleoside (N1) of mRNA to fit in the RNA binding pocket (Figure 1).
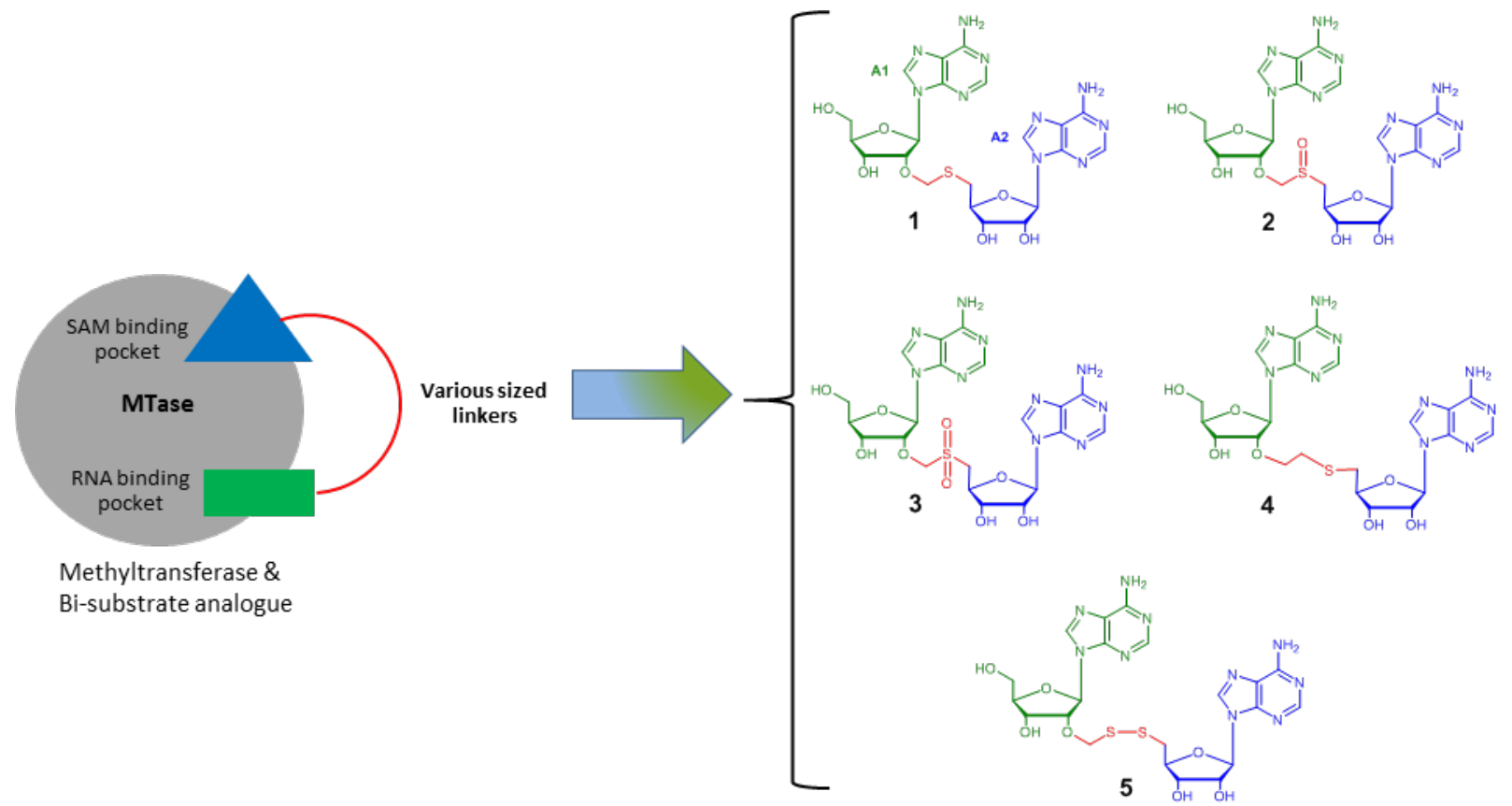

Figure 1. Rationale for designing a library of diverse bisubstrate SAM analogues for RNA 2'-O-methyltransferases

In the same way, several bisubstrates for diverse methyltransferases (DNA MTases, ${ }^{[8]}$ catechol MTase, ${ }^{[9]}$ protein MTases, ${ }^{[10]}$ nicotinamide MTase $^{[11]} \ldots$ ) have been previously reported in the literature. Nevertheless, it is noteworthy some relevant examples of the use of bisubstrate nucleosidic analogues for the study of nucleic acids methyltransferases. Particularly, P. Arimondo developed transition state analogues of DNA methylation based on the coupling of cytosine analogues to adenosine to give 5methylcytosine-adenosine compounds. ${ }^{[12]}$ Moreover, the first bisubstrates targeting RNA methyltransferases have been described in 1986 and one compound designed with the SAM moiety linked to the C6 of a guanine derivative demonstrated an inhibitory activity against vaccinia RNA N7guanine MTase for the N7-methylation of the 5'-cap structure. ${ }^{[13]}$ More recently, in the context of deciphering the roles of N6m-A RNA modifications and consequently exploring the functions of N6-A RNA MTases, SAM-adenosine conjugates mimicking the transition state of methylation at N6 were synthesized by connecting a SAM analogue to the N6-position of an adenosine unit via alkyl and urea 
linkers. ${ }^{[14]}$ The binding of these bisubstrate analogues for Ribosomal RNA large subunit MTase J (RlmJ) has been studied and they were shown to be useful as starting scaffolds for inhibitor design against m6A RNA MTases. ${ }^{[15]}$ Beside these few examples, none other RNA MTases have been targeted by bisubstrate analogues.

In this work, we report on the synthesis of five $S$-adenosyl-5'-thioadenosine conjugates as bisubstrate analogues for the study of RNA 2'-O-methyltransferases. All these compounds were designed with a 5'-thioadenosine linked to the 2'-OH of an adenosine unit through alkyl linkers of various length (methyl or ethyl) and/or different oxidation degrees of the sulfur atom. Indeed, we first focused on the sulfidecontaining linkers ( $S$-linkers) that represents the most fitting motives to mimic the SAM structure closely in comparison to other linkages with diverse heteroatoms in place of S. Moreover, $S$-linkers are attractive as they are stable and non-hydrolysable. This was previously shown with the synthesis of several 2'dialkyl $S$-linked dinucleosides which were incorporated into oligonucleotide analogues for the study of their hybridization properties in antisense purposes. ${ }^{[16]}$ Furthermore, the corresponding sulfoxides and sulfones are of interest for chemists as they result from simple thioether oxidation and these groups are commonly found in nature as well as in the structure of some active drugs (Disulone ${ }^{\circledR}$, Modiodal ${ }^{\circledR}$ ). The presence of sulfoxide and sulfone was also noted in aminoglycoside-Coenzyme A bisubstrates targeting aminoglycoside $N$-6'-acetyltransferase. ${ }^{[17]}$ Recently, two SAM structural analogues, a sulfoxide and a sulfone derived from SAH have been synthesized as substrates for the study of their reductive cleavage by radical SAM enzymes. ${ }^{[18]}$ In addition, it should be mentioned that a cytosine or a thymine dinucleoside 3',5'-bridged by a sulfone-containing linker has been described in the literature for the synthesis of stable sulfonyl-containing antisense oligonucleotides. ${ }^{[19]}$ Inspired by this work, the $S$-linked dinucleoside 1 has been oxidized in sulfoxide $(\mathrm{SO}, 2)$ or sulfone $\left(\mathrm{SO}_{2}, 3\right)$ since these sulfur functional groups might improve chemical stability and solubility in water of the bisubstrates (Figure 1). Likewise, the disulfide bridge represents an attractive functional group to design another $S$-linker. The disulfide bonds are widely found in natural biological systems and play a central role in protein stability, they are able to undergo disulfide-exchange reactions with thiols over a broad range of $\mathrm{pH}$. Interestingly, some disulfide dinucleosides as nicotinamide adenine dinucleotide (NAD) mimics were reported to inhibit several NAD kinases. ${ }^{[20]}$ In similar way, we linked two adenosines via an alkyl disulfide bond to yield the 2',5'-disulfanyl dinucleoside 5.

\section{Results and Discussion}

Synthesis of adenine dinucleoside 1 with a methylthioether linker. Two strategies have been tested to obtain the dinucleoside 1 with a methylthioether linker between both adenosines A1 and A2 (Figure 1). The first one has consisted in the coupling of 2'-O-acetylthiomethyl- $N^{6}$-phenoxyacetyl adenosine previously described by our group ${ }^{[21]}$, bearing a pro-nucleophile site at 2'-position, and the commercially available 5'-O-tosyl adenosine or 5'-Cl-adenosine, both bearing an electrophile site at 5'-position. A basic medium (7M NH $3 / \mathrm{MeOH}$ or $\mathrm{BuNH}_{2} / \mathrm{THF}$ ) released a nucleophilic thiolate at 2'-position of A1 prone to react with A2. Nevertheless, the dinucleoside coupling was unsuccessful due to the too fast degradation of the 2'-thiohemiacetal species into adenosine. In the second strategy, the reactivity centers were reversed in the synthons A1 and A2 with a thioacetyl group as the pro-nucleophile site at 5'position of A2 and a 2'-chloromethyl group as electrophile in A1. The coupling was similarly achieved in basic medium to generate the nucleophilic thiolate in A2, capable to attack the chloromethyl group.

Following this strategy, we first synthesized the 2'-chloromethyl derivative 6 from the commercial 3',5'$O$-tetraisopropyldisiloxane (TIPDS) $N^{6}$-phenoxyacetyl adenosine via a 2'-O-methylthiomethyl derivative (Pummerer rearrangement) upon a described procedure (Scheme 2). ${ }^{[21]}$ This compound 6 remains stable for $2 \mathrm{~h}$ at room temperature therefore requires a rapid utilization in the next coupling 
with a 5'-thiolate. In parallel, the introduction of the thioacetyl group at 5'-position of 2',3'isopropylideneadenosine was achieved by a Mitsonubu reaction with $98 \%$ yield to give compound 7 which was subsequently 2',3'-deprotected in acidic conditions affording 5 '-thioacetyl adenosine $\mathbf{8}^{\text {[22] }}$ Then, several basic conditions ( $7 \mathrm{M} \mathrm{NH}_{3} / \mathrm{MeOH} ; n \mathrm{BuNH}_{2}$ in THF; NaOMe / MeOH; $\mathrm{KOH} / \mathrm{MeOH}$ ) have been screened to give the thiolate derivatives of $\mathbf{7}$ or $\mathbf{8}$, and to compare the coupling efficiency with 6. It is worth mentioning that the 5'-thioacetyl adenosine $\mathbf{8}$ was totally converted into its thiolate derivative within short reaction times from $10 \mathrm{~min}$ with $\mathrm{KOH} / \mathrm{MeOH}$ to $30 \mathrm{~min}$ with other basic conditions whereas the 5'-thiolate of 2',3'-protected adenosine 7 was only formed at 50\% within $2 \mathrm{~h}$ with $\mathrm{NH}_{3} / \mathrm{MeOH}$ or $16 \mathrm{~h}$ with $\mathrm{NaOMe}$ or $\mathrm{KOH}$ in $\mathrm{MeOH}$. Consequently, the coupling was more efficient with 5'-thiolate from 8 than from 7. The 5',3'-TIPDS dinucleoside $\mathbf{1 0}$ was obtained with 61\% yield from the coupling of potassium thiolate salt of $\mathbf{8}$ with the chloromethyl nucleoside $\mathbf{6}$ in a mixture dichloromethane / methanol after $2 \mathrm{~h}$ reaction at room temperature. The last step was the removal of the TIPDS group with a fluoride ions treatment for $2 \mathrm{~h}$ at $50^{\circ} \mathrm{C}$ to release the $S$-(2'-O-methyladenosyl) 5'thioadenosine 1 with $89 \%$ yield and high purity after purification by C18-reversed-phase silica gel chromatography.

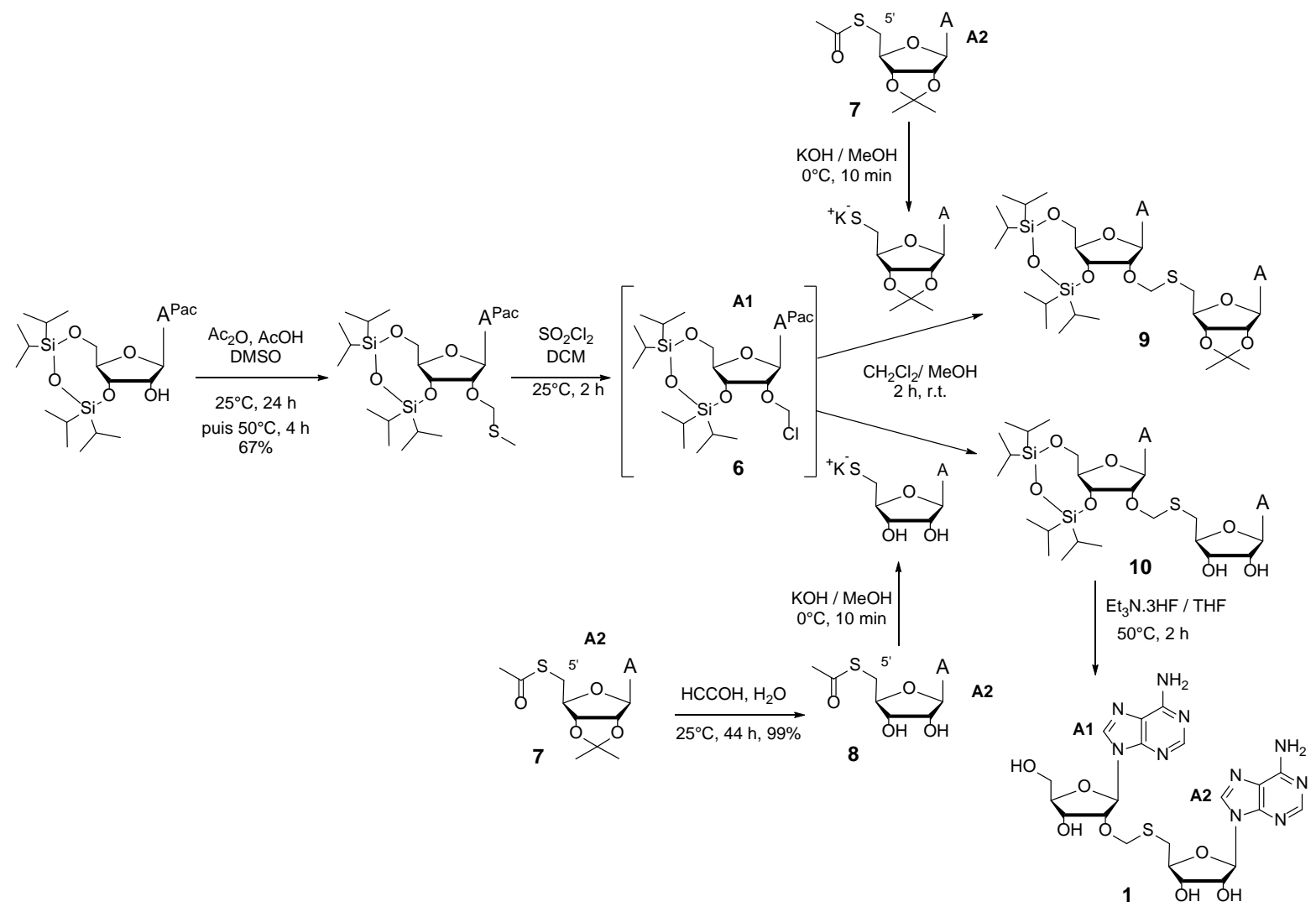

Scheme 2. Synthesis of $S$-(2'-O-methyladenosyl) 5'-thioadenosine 1. A $=$ adenine. $\mathrm{A}^{\mathrm{Pac}}=N^{6}$ phenoxyacetyl adenine

Synthesis of adenine dinucleosides 2 and 3 with sulfoxide- or sulfone-containing linkers. To extend the series of thioether-linked dinucleoside, sulfoxide- or sulfone-containing linkers were evidently designed. The ease of preparation of oxidized sulfides and the potential increase of affinity for enzymes by allowing two extra $\mathrm{H}$-bonds between the oxygen of $\mathrm{S}=\mathrm{O}$ and these two hydrogen bonds prompted us to oxidize the sulfur atom of dinucleoside $\mathbf{1}$ into sulfoxide $\mathbf{2}$ or sulfone $\mathbf{3}$ derivatives (Scheme 3 ). Selective oxidation of the sulfide can be performed with several oxidizing agents such as $\mathrm{m}$ chloroperbenzoic acid ( $m$-CPBA), sodium periodate, potassium hydrogen persulfate (oxone ${ }^{\circledR}$ ). 
However, $m$-CPBA was not soluble in the THF/MeOH/ $\mathrm{H}_{2} \mathrm{O}$ solution mixture required for dissolution of the substrate 1 and sodium periodate led to the oxidizing cleavage of the cis-diol-containing adenosine as a side reaction. Finally, oxone ${ }^{\circledR}$ was selected for its ease of use, stability, non-toxicity and solubility in the reaction mixture. The reaction with 3',5'-TIPDS dinucleoside $\mathbf{1 0}$ was complete after $3 \mathrm{~h}$ at $0^{\circ} \mathrm{C}$ after addition of three equivalents of oxidant in three portions. HPLC analysis of the crude material exhibited two peaks with a 68/32 ratio corresponding to the sulfoxide 11 and the sulfone 12, respectively. Dinucleosides 11 and 12 were isolated after purification with 30\% and 21\% yield, respectively. Then, $\mathbf{1 1}$ and 12 were deprotected with a fluoride treatment to give the sulfoxide dinucleoside $\mathbf{2}$ with $38 \%$ yield and the sulfone dinucleoside 3 with $32 \%$ yield after purification by $\mathrm{C}_{18}$ reversed-phase chromatography. HPLC analysis of 2 exhibits two peaks with 74/26 ratio corresponding to the two (R) and $(S)$ diastereoisomers. No attempt was made to determine the absolute stereochemistry at the sulfur atom. The sulfoxide-linked dinucleoside $\mathbf{2}$ will be first evaluated as a diastereoisomeric mixture in the inhibition assays.
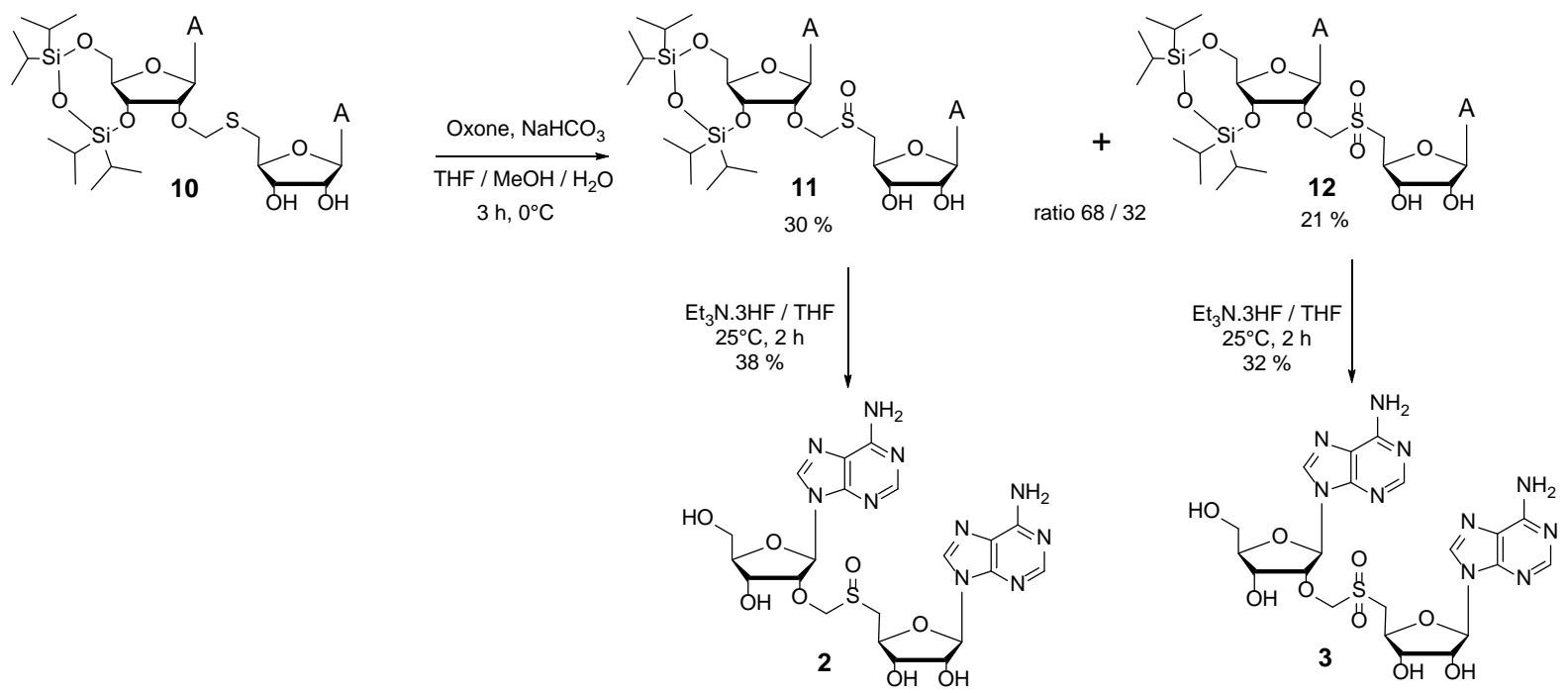

Scheme 3. Synthesis of $S$-(2'-O-methyladenosyl) 5'-sulfoxide adenosine 2 and $S$-(2'-O-methyladenosyl) 5'-sulfone adenosine 3

Synthesis of adenine dinucleoside 4 with an ethylthioether linker. The dinucleoside 4 with a longer ethylthioether linker than the one of $\mathbf{1}$ was synthesized by coupling the 2'-O-modified adenosine $\mathbf{1 3}$ with an electrophile site at 2'-position and the 5'-thiolate derivative from 8. Thus, the 2'-O-(tosylethyl) adenosine $\mathbf{1 3}$ was prepared in four steps from adenosine following a described procedure for the three first steps (Scheme 4). ${ }^{[23]}$ 

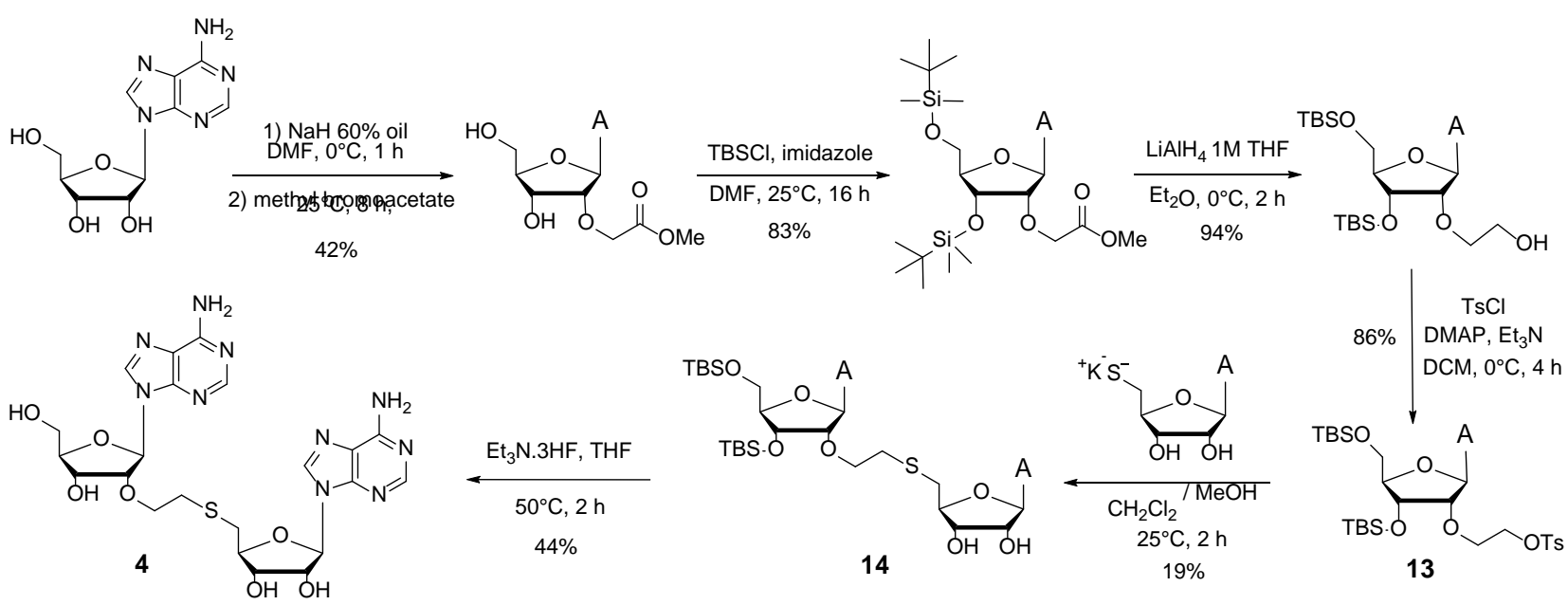

Scheme 4. Synthesis of S-(2'-O-ethyladenosyl)-5'-thioadenosine 4

The first step has consisted in introducing a methylester group preferentially at 2'-position whereas the 3' $-\mathrm{OH}$ and 5' $-\mathrm{OH}$ were unprotected. The reaction was conducted in the presence of $\mathrm{NaH}$ and the 2'-O(methoxycarbonylmethyl) adenosine was the main compound isolated with satisfactory $42 \%$ yield. The 3'- and 5'-isomers were also formed at a lower extent. The next step was the masking of 3'-OH and 5'$\mathrm{OH}$ by tert-butyldimethylsilyl (TBS) groups with $83 \%$ yield. The reduction of the ester function in the presence of $\mathrm{LiAlH}_{4}$ gave the 5',3'-O-TBS 2'-O-(2-hydroxyethyl) adenosine quantitatively. Unlike reported work described the alcohol activation with a mesylate group ${ }^{[23]}$ in our case the mesylate derivative was unstable and the coupling between both adenosines did not succeed. In contrast, the tosylate derivative $\mathbf{1 3}$ obtained with $86 \%$ yield was stable and was reacted with the 5'-potassium thiolate adenosine from 8 to give the 2', '5'-ethylthioether-linked dinucleoside 14 (19\%). ${ }^{[24]}$ This low yield would have been improved by addition of 18-crown-6 ether to increase the reactivity of the thiolate nevertheless preliminary assays had shown that the separation by gel chromatography of 14 from 18-C6 ether could not be achieved. Finally, an $\mathrm{Et}_{3} \mathrm{~N}$. 3HF treatment was applied to remove the TBS groups from 14 to afford the dinucleoside 4 in $44 \%$ yield after purification.

Synthesis of adenine dinucleoside with a disulfide linker 5 . To generate the disulfide bridge between two adenosines, a thiol-disulfide exchange reaction has been intended between a thiolate derivative at 2'-position of A1 and a 5'-disulfanylnitropyridine adenosine A2 in basic conditions with release of 2thio-5-nitropyridine. In a first attempt, the coupling was performed between one equivalent of 2'-Omethylthioacetyl $N^{6}$-Pac-adenosine $\mathbf{1 6}^{[21]}$ (at $58 \mathrm{mM}$ concentration) obtained from the chloromethyl derivative 6, and an excess (1.2 eq) of 5'-disulfanylnitropyridine adenosine 18 prepared from 5'acetylthioadenosine 8 (Scheme 5). ${ }^{[22 a]}$ The reaction was carried out at $0^{\circ} \mathrm{C}$ in the presence of $7 \mathrm{M}$ ammonia in methanol and after $15 \mathrm{~min}$, three peaks were noticed in the reverse-phase HPLC chromatogram with a 35/45/20 ratio (Figure S14). These three major peaks have been assigned to three dinucleosides with the linker attached at different positions in the adenosines (Scheme S1). The main peak corresponds to the desired dinucleoside 5 with a 2',5'-disulfide linker. The other peaks were assigned to the symmetrical dinucleosides with 2',2'- or 5',5'-disulfide-linker resulting from the coupling of synthon $\mathbf{1 6}$ or synthon $\mathbf{8}$ with themselves, respectively. 

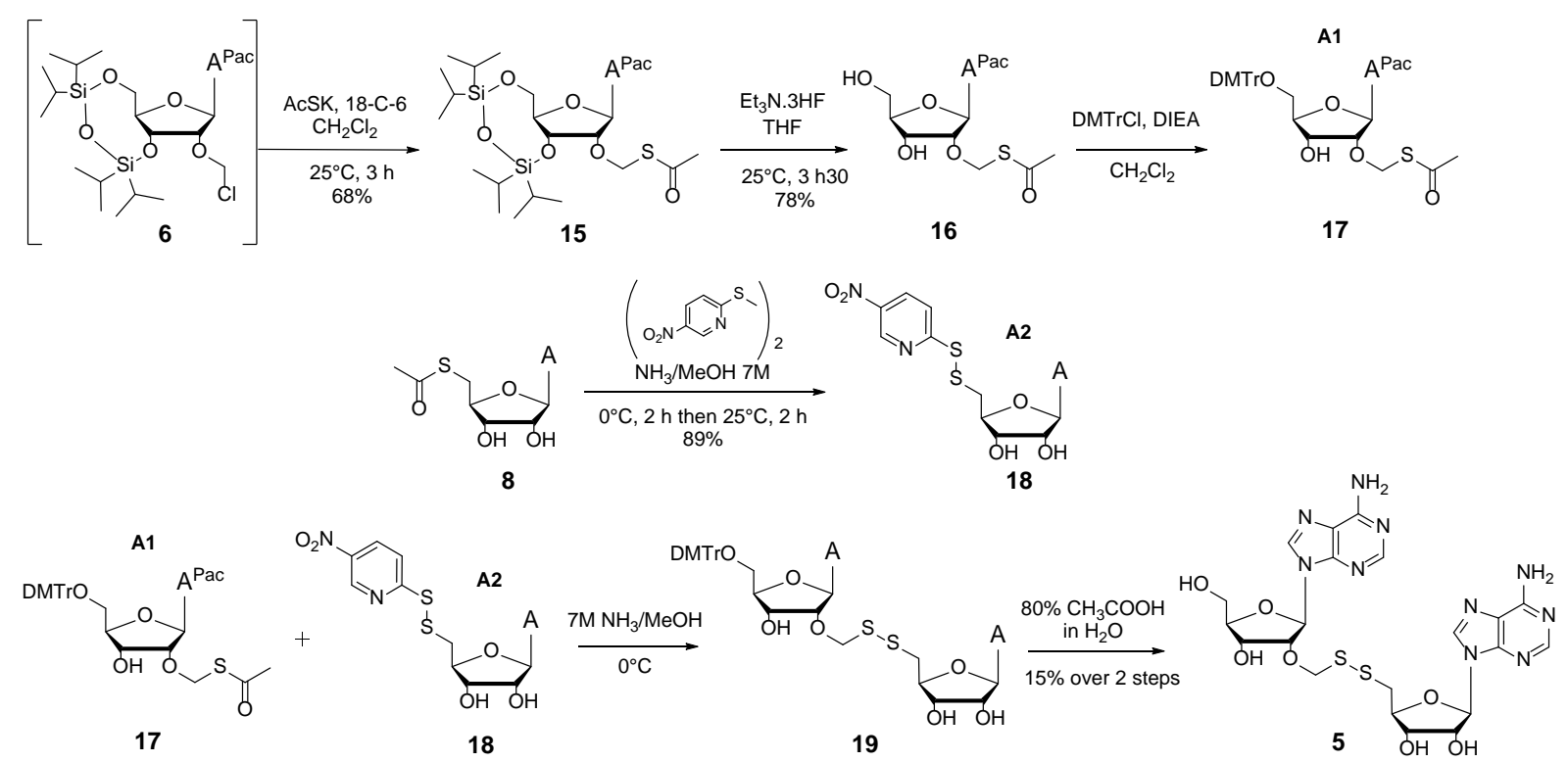

Scheme 5. Synthesis of S-(2'-O-methylthioadenosinyl)-5'-thioadenosine 5

Next, the conditions of the coupling reaction have been optimized to obtain the dinucleoside $\mathbf{5}$ with an improved yield. Either a higher $(91 \mathrm{mM})$ or a lower $(23 \mathrm{mM})$ concentration for $\mathbf{1 6}$ were tested and it was shown that a diluted solution of $\mathbf{1 6}$ at $23 \mathrm{mM}$ was favorable to a high proportion (73\%) of $\mathbf{5}$ in the crude mixture. In contrast, increasing the amount of $\mathbf{1 8}$ up to 3 equivalents rather promoted the formation of the 5',5'-disulfide link dinucleoside. However, even though in the optimized conditions, the dinucleoside $\mathbf{5}$ was the major compound in the mixture, we were not able to isolate $\mathbf{5}$ with high purity and in sufficient amount due to a delicate separation of the three dinucleosides which may be explained by the similarity of their structure. To improve this separation, we introduced the lipophilic dimethoxytrityl (DMTr) group at 5'-position of $\mathbf{1 6}$ to give 5'-O-DMTr 2'-O-SAc adenosine 17. This nucleoside 17 used at $23 \mathrm{mM}$ concentration was reacted with 1.8 equivalent of 18 in $7 \mathrm{M} \mathrm{NH}_{3} / \mathrm{MeOH}$ to give the three dinucleosides as previously. However, the ratio was different and the benefit of the lipophilicity of DMTr group was crucial for the separation since the dinucleoside with 2',2'-disulfide linker is DMTr-protected at both 5'-positions (Rt 15.66), the dinucleoside with 5',5'-disulfide linker is the most polar with both 5'-OH (Rt 4.29) and the dinucleoside 19 has only one DMTr group at 5'position of A1 (Rt 10.68) (Figure 2). It is noteworthy that to get rid of the remaining excess of 5'nitropyridinyl disulfide adenosine 18 by reverse-phase chromatography the use of a $50 \mathrm{mM}$ triethylammonium acetate buffer $\mathrm{pH} 7$ instead of water as eluent was recommended to avoid contamination of all the fractions by the nitropyridine derivative. Indeed, the pyridine moiety exists under protonated/deprotonated equilibrium in water and 18 spreads out all over the column chromatography. After purification, HPLC analysis showed that the isolated compound $\mathbf{1 9}$ was $\mathbf{7 5 \%}$ pure and 5'-O-DMTr adenosine was characterized as the main contaminant resulting from the total deprotection of $\mathbf{1 7}$ in basic medium during the coupling reaction. 


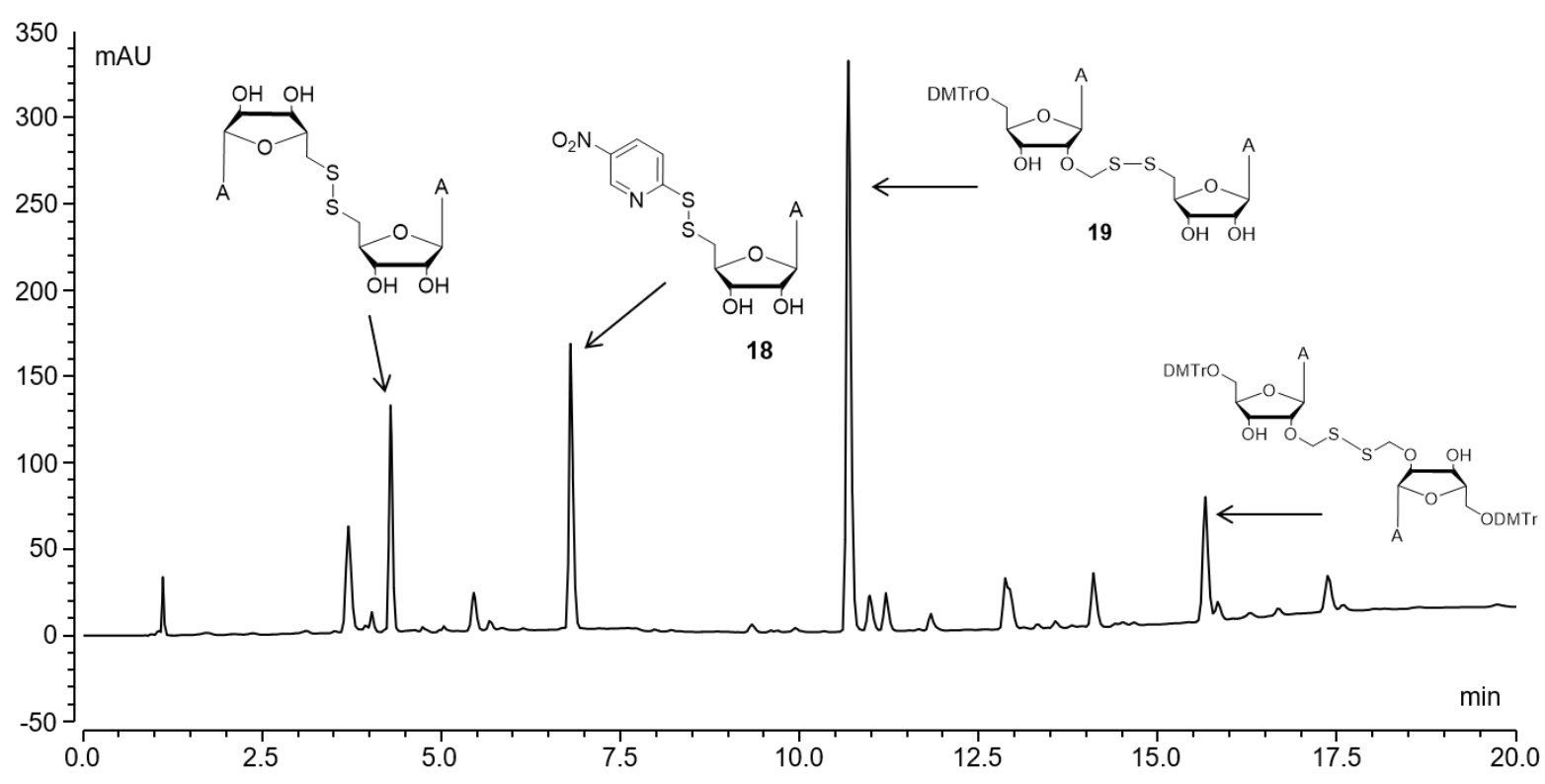

Figure 2. Reverse-phase HPLC profile of the crude mixture after the coupling reaction between 17 (23 $\mathrm{mM})$ and 18 (1.80 eq)

Finally, dinucleoside 19 was engaged in the last deprotection step to remove the DMTr group with 80\% acetic acid in water to give the disulfanyl-linked dinucleoside 5 that was isolated with high purity after purification by $\mathrm{C}_{18}$-chromatography in $15 \%$ yield over 2 steps (coupling and deprotection).

\section{Conclusion}

In this paper, we report the synthesis of five adenine dinucleosides with $S$-linkers as bisubstrate SAM analogues for 2'-O-methyltransferases that catalyze the 2'-O-methylation of the 5' cap of viral mRNA or at internal positions within RNA sequence. These bisubstrates contain a 5'-thioadenosine mimicking the SAM adenosine and attached to the 2'-position of another adenosine through an alkyl S-linker, mimicking the 5'-end of RNA substrate. Such analogues were designed as mimics of the transition state of the 2'-O-methylation of RNA with both partners of the reaction. The evaluation of the bisubstrate analogues as inhibitors of various 2'-O-MTases of emerging viruses (Zika, Dengue, Ebola, SARS, MERS) is currently in progress. Moreover, the $S$-linked adenine dinucleosides are valuable tools to start structural studies on viral MTases before further studies with short RNAs incorporating the bisubstrate molecules at 5'-end or at internal positions. Rationally, the prospects of this work stand the synthesis of new bisubstrates with other heteroatom-containing linkers therefore the synthesis of analogues with amine-type linkages $\left(\mathrm{OCH}_{2} \mathrm{CH}_{2} \mathrm{NR}_{2}\right)$ is ongoing.

\section{Experimental section}

General Methods. DIEA was distilled over calcium hydride. All dry solvents and reagents were purchased from commercial suppliers and were used without further purification. Thinlayer chromatography (TLC) analyses were carried out on silica plate $60 \mathrm{~F}_{254}$. Purifications by column chromatography were performed using Biotage Isolera 1 system with Column Flash Pure from Buchi. NMR experiments were recorded on Bruker 400, 500 or 600 spectrometers at $20^{\circ} \mathrm{C}$. HRMS analyses were obtained with electrospray ionization (ESI) in positive mode on 
a Q-TOF Micromass spectrometer. Analytical HPLC was performed on a UHPLC Thermoscientific Ultimate 3000 system equipped with a LPG-3400RS pump, a DAD 3000 detector and an WPS-3000TBRS Autosampler, Column Oven TCC-3000SD. Dinucleosides 15 were analyzed by RP-HPLC (Macherey Nagel Nucleodur $C_{18} 3 \mu \mathrm{m}, 4.6$ x $75 \mathrm{~mm}$ ). The following HPLC solvent systems were used: $1 \% \mathrm{CH}_{3} \mathrm{CN}$ in $12.5 \mathrm{mM}$ TEAAc (buffer A), 80\% $\mathrm{CH}_{3} \mathrm{CN}$ in $12.5 \mathrm{mM}$ TEEAc (buffer B). Flow rate was $1 \mathrm{~mL} / \mathrm{min}$. UV detection was performed at $260 \mathrm{~nm}$. Lyophilized compounds $\mathbf{1 - 5}$ were stored at $-20^{\circ} \mathrm{C}$ for several months without any degradation.

\section{S-(3',5'-(tetraisopropyldisiloxane-1,3-diyl)-2'-O-methyladenosyl)-5'-thioadenosine 10}

To a solution of 3',5'-O-tetraisopropyldisiloxane 2'-O-methylthiomethyl $N^{6}$-phenoxyacetyl adenosine ${ }^{[21]}(0.50 \mathrm{~g}, 0.71 \mathrm{mmol}, 1.00 \mathrm{eq})$ in anhydrous $\mathrm{CH}_{2} \mathrm{Cl}_{2}(2.50 \mathrm{~mL})$ was added $1.0 \mathrm{M}$ sulfuryl chloride $\left(\mathrm{SO}_{2} \mathrm{Cl}_{2}\right)$ in dichloromethane $(1.10 \mathrm{~mL}, 1.06 \mathrm{mmol}, 1.50 \mathrm{eq})$ diluted in anhydrous $\mathrm{CH}_{2} \mathrm{Cl}_{2}(2.50$ $\mathrm{mL}$ ) in a dropping funnel. The reaction mixture was stirred for $2 \mathrm{~h}$ at room temperature under argon. The solvent was removed under vacuum and the crude mixture of $\mathbf{6}$ was diluted in anhydrous $\mathrm{CH}_{2} \mathrm{Cl}_{2}$ (3 $\mathrm{mL}$ ). In parallel, 5'-thioacetyl adenosine 8 (0.39 mg, $1.20 \mathrm{mmol}$, $1.70 \mathrm{eq})$ suspended in $\mathrm{MeOH}$ (2 mL) in a round flask was treated with a solution of potassium hydroxide $\mathrm{KOH}(0.14 \mathrm{~g}, 2.49 \mathrm{mmol}$, $3.50 \mathrm{eq})$ in $\mathrm{MeOH}(4 \mathrm{~mL})$. The reaction mixture was stirred for $30 \mathrm{~min}$ at $0^{\circ} \mathrm{C}$ under argon. The chloromethyl derivative $\mathbf{6}$ was directly added to the solution containing the potassium thiolate of $\mathbf{8}$ and the reaction mixture was stirred for $2 \mathrm{~h}$ at room temperature under argon. The solvents were removed under vacuum, and the resulting residue was purified by silica gel chromatography (dry-loading) with a $0-15 \% \mathrm{MeOH}$ linear gradient in $\mathrm{CH}_{2} \mathrm{Cl}_{2}$ to give the dinucleoside 10 as a white solid $(0.35 \mathrm{~g}, 0.435 \mathrm{mmol}, 61 \%) . R_{\mathrm{f}}=$ $0.66\left(\mathrm{MeOH} / \mathrm{CH}_{2} \mathrm{Cl}_{2} 15: 85\right) ;{ }^{1} \mathrm{H}-\mathrm{NMR}\left(400 \mathrm{MHz}, \mathrm{DMSO}-\mathrm{d}_{6}\right) \delta=8.30\left(\mathrm{~s}, 1 \mathrm{H}, \mathrm{A}_{2} \mathrm{H}_{8}\right) ; 8.16(\mathrm{~s}, 1 \mathrm{H}$, $\left.\mathrm{A}_{1} \mathrm{H}_{8}\right) ; 8.13\left(\mathrm{~s}, 1 \mathrm{H}, \mathrm{A}_{2} \mathrm{H}_{2}\right) ; 8.06\left(\mathrm{~s}, 1 \mathrm{H}, \mathrm{A}_{1} \mathrm{H}_{2}\right) ; 7.33$ (s, $\left.2 \mathrm{H}, \mathrm{A}_{1} \mathrm{NH}_{2}\right) ; 7.26$ (s, $2 \mathrm{H}, \mathrm{A}_{2} \mathrm{NH}_{2}$ ) ; 5.99 (s, $\left.1 \mathrm{H}, \mathrm{A}_{1} \mathrm{H}_{1^{\prime}}\right) ; 5.85\left(\mathrm{~d}, \mathrm{~J}=5.7 \mathrm{~Hz}, 1 \mathrm{H}, \mathrm{A}_{2} \mathrm{H}_{1^{\prime}}\right) ; 5.50\left(\mathrm{~d}, \mathrm{~J}=6.0 \mathrm{~Hz}, 1 \mathrm{H}, \mathrm{A}_{2} \mathrm{OH}_{2^{\prime}}\right) ; 5.29(\mathrm{~d}, \mathrm{~J}=5.1 \mathrm{~Hz}, 1 \mathrm{H}$, $\left.\mathrm{A}_{2} \mathrm{OH}_{3^{\prime}}\right) ; 5.04\left(\mathrm{~m}, 1 \mathrm{H}, \mathrm{A}_{1} \mathrm{H}_{3^{\prime}}\right) ; 5.03\left(\mathrm{~d}, \mathrm{~J}=11.7 \mathrm{~Hz}, 1 \mathrm{H}, \mathrm{OCH}_{2} \mathrm{~S}\right) ; 4.93\left(\mathrm{~d}, \mathrm{~J}=11.6 \mathrm{~Hz}, 1 \mathrm{H}, \mathrm{OCH}_{2} \mathrm{~S}\right)$; $4.81\left(\mathrm{~d}, \mathrm{~J}=5.1 \mathrm{~Hz}, 1 \mathrm{H}, \mathrm{A}_{1} \mathrm{H}_{2}\right.$ ) ; $4.77\left(\mathrm{q}, \mathrm{J}=5.7 \mathrm{~Hz}, \mathrm{~J}=11.1 \mathrm{~Hz}, 1 \mathrm{H}, \mathrm{A}_{2} \mathrm{H}_{2}\right.$ ) ; $4.14(\mathrm{q}, \mathrm{J}=4.9 \mathrm{~Hz}, \mathrm{~J}=$ $9.0 \mathrm{~Hz}, 1 \mathrm{H}, \mathrm{A}_{2} \mathrm{H}_{3^{\prime}}$ ) ; 4.02-4.07 (m, $\left.2 \mathrm{H}, \mathrm{A}_{2} \mathrm{H}_{4}, \mathrm{~A}_{1} \mathrm{H}_{5}^{\mathrm{x}}\right)$; 3.90-3.99 (m, $\left.2 \mathrm{H}, \mathrm{A}_{1} \mathrm{H}_{4}, \mathrm{~A}_{1} \mathrm{H}_{5}^{\mathrm{x}}\right)$; 2.87 - 3.06 (m, $2 \mathrm{H}, \mathrm{A}_{2} \mathrm{H}_{5}, \mathrm{~A}_{2} \mathrm{H}_{5}$ ") ; $0.96-1.03$ (m, 28H, $\mathrm{H}_{\text {TIPDS }}$ ). ${ }^{13} \mathrm{C}-\mathrm{NMR}$ (150 MHz, DMSO-d ${ }_{6}$ ) $\delta=156.11 \& 156.09$ $\left(\mathrm{A}_{1} \mathrm{C}_{6} \& \mathrm{~A}_{2} \mathrm{C}_{6}\right) ; 152.6$ \& $152.5\left(\mathrm{~A}_{1} \mathrm{C}_{2} \& \mathrm{~A}_{2} \mathrm{C}_{2}\right) ; 149.4\left(\mathrm{~A}_{2} \mathrm{C}_{4}\right) ; 148.5\left(\mathrm{~A}_{1} \mathrm{C}_{4}\right) ; 139.9\left(\mathrm{~A}_{2} \mathrm{C}_{8}\right) ; 139.5$ $\left(\mathrm{A}_{1} \mathrm{C}_{8}\right) ; 119.3\left(\mathrm{~A}_{1} \mathrm{C}_{5}\right) ; 119.2\left(\mathrm{~A}_{2} \mathrm{C}_{5}\right) ; 87.7 \& 87.5\left(\mathrm{~A}_{1} \mathrm{C}_{1}, \& \mathrm{~A}_{2} \mathrm{C}_{1}\right) ; 83.5\left(\mathrm{~A}_{2} \mathrm{C}_{4}\right) ; 80.7\left(\mathrm{~A}_{1} \mathrm{C}_{4}\right) ; 77.3$ $\left(\mathrm{A}_{1} \mathrm{C}_{2}{ }^{\prime}\right)$; 72.72, 72,68, 72,57 ( $\left.\mathrm{OCH}_{2} \mathrm{~S}, \mathrm{~A}_{2} \mathrm{C}_{2}, \mathrm{~A}_{2} \mathrm{C}_{3^{\prime}}\right) ; 69.7\left(\mathrm{~A}_{1} \mathrm{C}_{3^{\prime}}\right) ; 60.1\left(\mathrm{~A}_{1} \mathrm{C}_{5^{\prime}}\right) ; 32.1\left(\mathrm{~A}_{2} \mathrm{C}_{5^{\prime}}\right) ; 17.32$ - 12.05 (C

\section{S-(2'-O-methyladenosyl)-5'-thioadenosine 1}

To a solution of $10(0.10 \mathrm{~g}, 0.12 \mathrm{mmol}, 1.00 \mathrm{eq})$ in anhydrous THF $(6 \mathrm{~mL})$ was added $1 \mathrm{M} \mathrm{Et}_{3} \mathrm{~N}-3 \mathrm{HF}$ solution in THF ( $60 \mu \mathrm{L}, 3.72 \mathrm{mmol}, 3.00 \mathrm{eq})$. After stirring for $2 \mathrm{~h}$ at $50^{\circ} \mathrm{C}$, the reaction mixture was treated with $2 \mathrm{M}$ triethylammonium acetate buffer ( $\mathrm{pH}$ 7). The solvents were removed under vacuum then water $(10 \mathrm{~mL})$ and $\mathrm{CH}_{2} \mathrm{Cl}_{2}(10 \mathrm{~mL})$ were added. The aqueous layer was extracted three times with $\mathrm{CH}_{2} \mathrm{Cl}_{2}$ and once with $\mathrm{Et}_{2} \mathrm{O}$ and was evaporated under vacuum. The resulting residue was purified by chromatography on reversed-phase silica gel column $\mathrm{C}_{18}(4 \mathrm{~g}, 40 \mu \mathrm{m})$ with a 0-25\% acetonitrile linear gradient in TEAAc buffer $50 \mathrm{mM}, \mathrm{pH}$ 7. The fractions containing the pure compound were pooled, concentrated and lyophilized to give 1 as a white powder (62 mg, $110 \mu \mathrm{mol}, 89 \%$ ) with 99\% purity determined by HPLC analysis at $260 \mathrm{~nm}$. ${ }^{1} \mathrm{H}-\mathrm{NMR}\left(600 \mathrm{MHz}, \mathrm{DMSO}-\mathrm{d}_{6}\right) \delta=8.35\left(\mathrm{~s}, 1 \mathrm{H}, \mathrm{A}_{1} \mathrm{H}_{8}\right) ; 8.29$ (s, $\left.1 \mathrm{H}, \mathrm{A}_{2} \mathrm{H}_{8}\right) ; 8.13 \& 8.14\left(2 \mathrm{~s}, 2 \mathrm{H}, \mathrm{A}_{1} \mathrm{H}_{2} \& \mathrm{~A}_{2} \mathrm{H}_{2}\right) ; 7.33\left(\mathrm{~s}, 2 \mathrm{H}, \mathrm{A}_{2} \mathrm{NH}_{2}\right) ; 7.28\left(\mathrm{~s}, 2 \mathrm{H}, \mathrm{A}_{1} \mathrm{NH}_{2}\right) ; 6.03$ (d, $\mathrm{J}=5.9 \mathrm{~Hz}, 1 \mathrm{H}, \mathrm{A}_{1} \mathrm{H}_{1}$ ) ; $5.83\left(\mathrm{~d}, \mathrm{~J}=5.9 \mathrm{~Hz}, 1 \mathrm{H}, \mathrm{A}_{2} \mathrm{H}_{1^{\prime}}\right) ; 5.47\left(\mathrm{~d}, J=6.1 \mathrm{~Hz}, 1 \mathrm{H}, \mathrm{A}_{2} \mathrm{OH}_{2}\right.$ ) ; 5.45 (m, 
$\left.1 \mathrm{H}, \mathrm{A}_{1} \mathrm{OH}_{5^{\prime}}\right) ; 5.28\left(\mathrm{~d}, \mathrm{~J}=5.3 \mathrm{~Hz}, 1 \mathrm{H}, \mathrm{A}_{1} \mathrm{OH}_{3^{\prime}}\right) ; 5.24\left(\mathrm{~d}, J=5.3 \mathrm{~Hz}, 1 \mathrm{H}, \mathrm{A}_{2} \mathrm{OH}_{3^{\prime}}\right) ; 4.81(\mathrm{~d}, J=11.7$ $\left.\mathrm{Hz}, 1 \mathrm{H}, \mathrm{OCH}_{2} \mathrm{~S}\right) ; 4.76\left(\mathrm{t}, J=5.3 \mathrm{~Hz}, 1 \mathrm{H}, \mathrm{A}_{1} \mathrm{H}_{2}\right) ; 4.69\left(\mathrm{~d}, J=11.7 \mathrm{~Hz}, 1 \mathrm{H}, \mathrm{OCH}_{2} \mathrm{~S}\right) ; 4.67(\mathrm{q}, J=5.8$ $\left.\mathrm{Hz}, J=11.2 \mathrm{~Hz}, 1 \mathrm{H}, \mathrm{A}_{2} \mathrm{H}_{2^{\prime}}\right) ; 4.35\left(\mathrm{~m}, 1 \mathrm{H}, \mathrm{A}_{1} \mathrm{H}_{3^{\prime}}\right.$ ) ; $4.03\left(\mathrm{~m}, 1 \mathrm{H}, \mathrm{A}_{2} \mathrm{H}_{3^{\prime}}\right.$ ) ; $3.98(\mathrm{q}, J=3.4 \mathrm{~Hz}, J=6.9$ $\left.\mathrm{Hz}, 1 \mathrm{H}, \mathrm{A}_{1} \mathrm{H}_{4^{\prime}}\right) ; 3.94\left(\mathrm{~m}, 1 \mathrm{H}, \mathrm{A}_{2} \mathrm{H}_{4}{ }^{\prime}\right) ; 3.69 \& 3.56\left(2 \mathrm{~m}, 2 \mathrm{H}, \mathrm{A}_{1} \mathrm{H}_{5^{\prime}}\right.$ \& $\mathrm{A}_{1} \mathrm{H}_{5^{\prime}}$ ) ; 2.73 (dd, $J=1.4 \mathrm{~Hz}, J=$ 6.7 Hz, 2H, $\left.\mathrm{A}_{2} \mathrm{H}_{5}, \& \mathrm{~A}_{2} \mathrm{H}_{5}{ }^{\prime}\right) .{ }^{13} \mathrm{C}-\mathrm{NMR}\left(150 \mathrm{MHz}, \mathrm{DMSO}-\mathrm{d}_{6}\right) \delta=156.14 \& 156.05\left(\mathrm{~A}_{1} \mathrm{C}_{6} \& \mathrm{~A}_{2} \mathrm{C}_{6}\right)$; $152.7 \& 152.5\left(\mathrm{~A}_{1} \mathrm{C}_{2} \& \mathrm{~A}_{2} \mathrm{C}_{2}\right) ; 149.4\left(\mathrm{~A}_{2} \mathrm{C}_{4}\right) ; 148.9\left(\mathrm{~A}_{1} \mathrm{C}_{4}\right) ; 139.7\left(\mathrm{~A}_{2} \mathrm{C}_{8}\right) ; 139.6\left(\mathrm{~A}_{1} \mathrm{C}_{8}\right) ; 119.3\left(\mathrm{~A}_{2} \mathrm{C}_{5}\right)$ ; $119.1\left(\mathrm{~A}_{1} \mathrm{C}_{5}\right)$; $87.3\left(\mathrm{~A}_{2} \mathrm{C}_{1^{\prime}}\right)$; $86.3\left(\mathrm{~A}_{1} \mathrm{C}_{4^{\prime}}\right)$; $86.1\left(\mathrm{~A}_{1} \mathrm{C}_{1^{\prime}}\right)$; $83.6\left(\mathrm{~A}_{2} \mathrm{C}_{4^{\prime}}\right)$; $78.2\left(\mathrm{~A}_{1} \mathrm{C}_{2}{ }^{\prime}\right) ; 72.7\left(\mathrm{OCH}_{2} \mathrm{~S}\right)$; $72.6\left(\mathrm{~A}_{2} \mathrm{C}_{2}{ }^{\prime}\right) ; 72.5\left(\mathrm{~A}_{2} \mathrm{C}_{3^{\prime}}\right) ; 68.9\left(\mathrm{~A}_{1} \mathrm{C}_{3^{\prime}}\right) ; 61.4\left(\mathrm{~A}_{1} \mathrm{C}_{5^{\prime}}\right) ; 32.2\left(\mathrm{~A}_{2} \mathrm{C}_{5^{\prime}}\right)$. HRMS (ESI+): m/z calcd for $\mathrm{C}_{21} \mathrm{H}_{27} \mathrm{~N}_{10} \mathrm{O}_{7} \mathrm{~S}[\mathrm{M}+\mathrm{H}]^{+}:$563.1785, found: 563.1786.

$S$-(3',5'-(tetraisopropyldisiloxane-1,3-diyl)-2'-O-methyladenosyl)-5'-sulfoxide adenosine 11 \& $S$ (3',5'-(tetraisopropyldisiloxane-1,3-diyl)-2'-O-methyladenosyl)-5'-sulfone adenosine 12

Compound 10 (0.93 mg, $1.16 \mathrm{mmol}, 1.00 \mathrm{eq})$ was suspended in a mixture of THF (7 mL), MeOH (7 $\mathrm{mL})$ and water $(1.80 \mathrm{~mL})$. After sonication, $\mathrm{NaHCO}_{3}(0.378 \mathrm{~g}, 4.52 \mathrm{mmol}, 3.90 \mathrm{eq})$ and oxone ${ }^{\circledR}(0.177$ g, $1.16 \mathrm{mmol}, 1.00 \mathrm{eq})$ were added. After $1 \mathrm{~h}$ stirring at room temperature under argon, an additional equivalent of oxone ${ }^{\circledR}$ was added and the reaction mixture was stirred for an additional hour. Another additional equivalent of oxone ${ }^{\circledR}$ was added and the reaction mixture was stirred again for an additional hour. The solution was then quenched with saturated aqueous $\mathrm{NaHCO}_{3}(10 \mathrm{~mL})$. The aqueous layer was extracted with AcOEt $(6 \times 50 \mathrm{~mL})$ and the combined organic extracts were washed with saturated aqueous $\mathrm{NaCl}\left(3 \times 50 \mathrm{~mL}\right.$ ), dried over $\mathrm{Na}_{2} \mathrm{SO}_{4}$ and concentrated under vacuum. The residue was purified via chromatography (dry-loading). Compound 12 was first eluted with $14 \% \mathrm{MeOH}$ in AcOEt and isolated as a white solid $(0.20 \mathrm{~g}, 0.239 \mathrm{mmol}, 21 \%)$. Compound 11 was isolated as a white solid $(0.288$ g, $0.351 \mathrm{mmol}, 30 \%$ ) after elution with $18 \% \mathrm{MeOH}$ in AcOEt.

(11) $R_{\mathrm{f}}=0.30\left(\mathrm{MeOH} / \mathrm{CH}_{2} \mathrm{Cl}_{2} 15: 85\right) .{ }^{1} \mathrm{H}-\mathrm{NMR}\left(600 \mathrm{MHz}, \mathrm{DMSO}-\mathrm{d}_{6}\right) \delta=8.33 ; 8.31 ; 8.19 ; 8.18$; $8.14 ; 8.13 ; 8.04 ; 8.04 ; 7.33 ; 7.28 ; 5.90 ; 5.59 ; 5.56 ; 5.45 ; 5.09 ; 5.06 ; 4.90 ; 4.82 ; 4.79-4.73$; $4.39-4.31 ; 4.26-4.19 ; 4.05-3.96 ; 3.92 ; 3.90-3.82 ; 3.28-3.16 ; 1.11-0.80 .{ }^{13} \mathrm{C}-\mathrm{NMR}(150$ MHz, DMSO-d 6 ) $\delta=156.11 ; 152.57 ; 152.46 ; 149.21 ; 149.17 ; 148.49 ; 148.47 ; 140.19 ; 139.85$; 139.79 ; 119.34 ; 119.32 ; 119.28 ; 88.32 ; 88.01 ; 87.68 ; 87.45 ; 86.45 ; 85.88 ; 83.57 ; 80.35 ; 80.28 ; 79.18 ; 78.97 ; $78.75 ; 77.33$; 76.62 ; 73.31 ; 73.23 ; 72.77 ; $72.74 ; 69.97 ; 69.91 ; 60.11 ; 51.22 ; 49.25$ ; 17.29 - 11.99. HRMS (ESI+): m/z calcd for $\mathrm{C}_{33} \mathrm{H}_{53} \mathrm{~N}_{10} \mathrm{O}_{9} \mathrm{SSi}_{2}: 821.32507$, found: 821.32287.

(12) $R_{\mathrm{f}}=0.50\left(\mathrm{MeOH} / \mathrm{CH}_{2} \mathrm{Cl}_{2} 15: 85\right) .{ }^{1} \mathrm{H}-\mathrm{NMR}\left(600 \mathrm{MHz}, \mathrm{DMSO}-\mathrm{d}_{6}\right) \delta=8.35$ (s, $\left.1 \mathrm{H}, \mathrm{A}_{\mathrm{x}} \mathrm{H}_{8}\right) ; 8.18$ (s, $\left.1 \mathrm{H}, \mathrm{A}_{\mathrm{x}} \mathrm{H}_{8}\right) ; 8.18\left(\mathrm{~s}, 1 \mathrm{H}, \mathrm{A}_{x} \mathrm{H}_{2}\right) ; 8.03\left(\mathrm{~s}, 1 \mathrm{H}, \mathrm{A}_{\mathrm{x}} \mathrm{H}_{2}\right) ; 7.35\left(\mathrm{~s}, 2 \mathrm{H}, \mathrm{A}_{\mathrm{x}} \mathrm{NH}_{2}\right) ; 7.29\left(\mathrm{~s}, 2 \mathrm{H}, \mathrm{A}_{\mathrm{x}} \mathrm{NH}_{2}\right) ; 6.02$ (s, $1 \mathrm{H}, \mathrm{A}_{1} \mathrm{H}_{1^{\prime}}$ ) ; 5.91 (d, $J=5.5 \mathrm{~Hz}, 1 \mathrm{H}, \mathrm{A}_{2} \mathrm{H}_{1^{\prime}}$ ) ; 5.64 (d, $\left.J=5.8 \mathrm{~Hz}, 1 \mathrm{H}, \mathrm{A}_{2} \mathrm{OH}_{2^{\prime}}\right) ; 5.55$ (d, $J=5.0 \mathrm{~Hz}$, $1 \mathrm{H}, \mathrm{A}_{2} \mathrm{OH}_{3^{\prime}}$ ) ; 5.06 (dd, $J=9.2,4.8 \mathrm{~Hz}, 1 \mathrm{H}, \mathrm{A}_{1} \mathrm{H}_{3^{\prime}}$ ) ; 4.96 (d, $J=4.8 \mathrm{~Hz}, 1 \mathrm{H}, \mathrm{A}_{1} \mathrm{H}_{2}$ ) ; 4.90 (d, $J=12.3$ $\left.\mathrm{Hz}, 1 \mathrm{H}, \mathrm{OCH}_{2} \mathrm{SO}_{2}\right) ; 4.78$ (q, $J=5.3 \mathrm{~Hz}, 1 \mathrm{H}, \mathrm{A}_{2} \mathrm{H}_{2}$ ) ; 4.63 (d, $\left.J=12.3 \mathrm{~Hz}, 1 \mathrm{H}, \mathrm{OCH}_{2} \mathrm{SO}_{2}\right) ; 4.31$ (dt, $J$ $\left.=9.2,3.5 \mathrm{~Hz}, 1 \mathrm{H}, \mathrm{A}_{2} \mathrm{H}_{4^{\prime}}\right) ; 4.28-4.17\left(\mathrm{~m}, 1 \mathrm{H}, \mathrm{A}_{2} \mathrm{H}_{3^{\prime}}\right) ; 4.04-3.91\left(\mathrm{~m}, 2 \mathrm{H}, \mathrm{A}_{1} \mathrm{H}_{5^{\prime}}, \mathrm{A}_{2} \mathrm{H}_{5^{\prime}}\right) ; 3.82-3.76$ (m, $1 \mathrm{H}, \mathrm{A}_{2} \mathrm{H}_{5}$ ") ; 3.71 (dt, $J=9.1,2.7 \mathrm{~Hz}, 1 \mathrm{H}, \mathrm{A}_{1} \mathrm{H}_{4}$ ) ; $3.59-3.49$ (m, $1 \mathrm{H}, \mathrm{A}_{1} \mathrm{H}_{5^{\prime}}$ ) ; $1.06-0.79$ (m, 28H, $\left.\mathrm{H}_{\text {TIPDS }}\right) .{ }^{13} \mathrm{C}-\mathrm{NMR}\left(150 \mathrm{MHz}, \mathrm{DMSO}-\mathrm{d}_{6}\right) \delta=156.15 \& 156.13\left(\mathrm{~A}_{1} \mathrm{C}_{6} \& \mathrm{~A}_{2} \mathrm{C}_{6}\right) ; 152.59 \& 152.51$ $\left(\mathrm{A}_{1} \mathrm{C}_{2} \& \mathrm{~A}_{2} \mathrm{C}_{2}\right) ; 149.20\left(\mathrm{~A}_{2} \mathrm{C}_{4}\right) ; 148.51\left(\mathrm{~A}_{1} \mathrm{C}_{4}\right) ; 139.96 \& 139.94\left(\mathrm{~A}_{1} \mathrm{C}_{8} \& \mathrm{~A}_{2} \mathrm{C}_{8}\right) ; 119.33$ \& 119.22 $\left(\mathrm{A}_{1} \mathrm{C}_{5} \& \mathrm{~A}_{2} \mathrm{C}_{5}\right)$; $88.08\left(\mathrm{~A}_{2} \mathrm{C}_{1^{\prime}}\right)$; $87.14\left(\mathrm{~A}_{1} \mathrm{C}_{1^{\prime}}\right) ; 83.72\left(\mathrm{OCH}_{2} \mathrm{SO}_{2}\right) ; 83.11\left(\mathrm{~A}_{1} \mathrm{C}_{2}{ }^{\prime}\right) ; 80.03\left(\mathrm{~A}_{1} \mathrm{C}_{4}{ }^{\prime}\right)$; 78.28 $\left(\mathrm{A}_{2} \mathrm{C}_{4^{\prime}}\right) ; 73.12\left(\mathrm{~A}_{2} \mathrm{C}_{3^{\prime}}\right) ; 72.32\left(\mathrm{~A}_{2} \mathrm{C}_{2}{ }^{\prime}\right) ; 70.02\left(\mathrm{~A}_{1} \mathrm{C}_{3^{\prime}}\right) ; 59.74\left(\mathrm{~A}_{2} \mathrm{C}_{5^{\prime}}\right) ; 52.76\left(\mathrm{~A}_{1} \mathrm{C}_{5^{\prime}}\right) ; 17.27-12.03$ (C $\left.\mathrm{C}_{\text {TIPDS}}\right)$. HRMS (ESI+): $\mathrm{m} / \mathrm{z}$ calcd for $\mathrm{C}_{33} \mathrm{H}_{53} \mathrm{~N}_{10} \mathrm{O}_{10} \mathrm{SSi}_{2}$ : 837.31999, found: 837.31950.

\section{S-(2'-O-methyladenosyl)-5'-sulfoxide adenosine 2}

To a solution of 11 (0.10 g, $0.12 \mathrm{mmol}, 1.00 \mathrm{eq})$ in anhydrous THF (6 mL) was added $\mathrm{Et}_{3} \mathrm{~N}-3 \mathrm{HF}$ (60 $\mu \mathrm{L}, 3.66 \mathrm{mmol}, 3.00 \mathrm{eq})$. After $2 \mathrm{~h}$ stirring at $25^{\circ} \mathrm{C}$, the reaction mixture was treated with $2 \mathrm{M}$ 
triethylammonium acetate buffer $(\mathrm{pH} 7)$. The solvents were removed under vacuum then water $(10 \mathrm{~mL})$ and $\mathrm{CH}_{2} \mathrm{Cl}_{2}(10 \mathrm{~mL})$ were added. The aqueous layer was extracted three times with $\mathrm{CH}_{2} \mathrm{Cl}_{2}$ and once with $\mathrm{Et}_{2} \mathrm{O}$ and was evaporated under vacuum. The resulting residue was purified by chromatography on a $\mathrm{C}_{18}$ reversed-phase silica gel column ( $\left.4 \mathrm{~g}, 40 \mu \mathrm{m}\right)$ with a $0-25 \%$ acetonitrile linear gradient in $50 \mathrm{mM}$ TEAAc buffer, $\mathrm{pH}$ 7. The fractions containing the pure compound were pooled, concentrated and lyophilized to give 2 as a white powder ( $27 \mathrm{mg}, 47 \mu \mathrm{mol}$, 39\%) with 98\% purity determined by HPLC analysis at $260 \mathrm{~nm} .{ }^{1} \mathrm{H}-\mathrm{NMR}(600 \mathrm{MHz}$, DMSO-d 6 ) $\delta=8.35 ; 8.33 ; 8.32 ; 8.14 ; 8.13 ; 7.34 ; 7.30$; $6.10 ; 6.07$; $5.90 ; 5.59$; 5.57 ; 5.54 ; 5.47 ; 5.44 ; 5.39 ; $4.85 ; 4.82 ; 4.72$; 4.68 ; 4.61 ; $4.40 ; 4.36$; $4.25 ; 4.20$ - $4.14 ; 3.99 ; 3.66 ; 3.58-3.50 ; 3.30 ; 3.26$ - $3.21 ; 3.18$; 3.09. ${ }^{13} \mathrm{C}-\mathrm{NMR}(150 \mathrm{MHz}$, DMSO-d $\left._{6}\right) \delta=156.61 ; 156.56 ; 153.13 ; 153.03 ; 153.00 ; 149.77 ; 149.67 ; 149.45 ; 140.57 ; 140.35$; 140.18 ; 140.13 ; $119.74 ; 119.68$; 88.55 ; 88.32 ; 86.53 ; 86.36 ; 86.29 ; 85.45 ; 83.78 ; 83.39 ; 78.47 ; 77.92 ; $73.61 ; 73.45 ; 73.24 ; 73.01 ; 69.53 ; 69.42 ; 61.73$; 51.29 ; 50.44. HRMS (ESI+): m/z calcd for $\mathrm{C}_{21} \mathrm{H}_{27} \mathrm{~N}_{10} \mathrm{O}_{8} \mathrm{~S}:$ 579.17286, found: 579.17224.

\section{S-(2'-O-methyladenosyl)-5'-sulfone adenosine 3}

To a solution of 12 ( $0.10 \mathrm{~g}, 0.12 \mathrm{mmol}, 1.00 \mathrm{eq})$ in anhydrous THF (6 mL) was added $\mathrm{Et}_{3} \mathrm{~N}-3 \mathrm{HF}$ (60 $\mu \mathrm{L}, 3.59 \mathrm{mmol}, 3.00 \mathrm{eq})$. After $2 \mathrm{~h}$ stirring at $25^{\circ} \mathrm{C}$, the reaction mixture was treated with $2 \mathrm{M}$ triethylammonium acetate buffer $(\mathrm{pH} 7)$. The solvents were removed under vacuum then water $(10 \mathrm{~mL})$ and $\mathrm{CH}_{2} \mathrm{Cl}_{2}(10 \mathrm{~mL})$ were added. The aqueous layer was extracted three times with $\mathrm{CH}_{2} \mathrm{Cl}_{2}$ and once with $\mathrm{Et}_{2} \mathrm{O}$ and was evaporated under vacuum. The resulting residue was purified by chromatography on a $\mathrm{C}_{18}$ reversed-phase silica gel column ( $4 \mathrm{~g}, 40 \mu \mathrm{m}$ ) with a $0-25 \%$ acetonitrile linear gradient in $50 \mathrm{mM}$ TEAAc buffer, $\mathrm{pH}$ 7. The fractions containing the pure compound were pooled, concentrated and lyophilized to give 3 as a white powder ( $23 \mathrm{mg}, 39 \mu \mathrm{mol}$, 32\%) with 98\% purity determined by HPLC analysis at $260 \mathrm{~nm} .{ }^{1} \mathrm{H}-\mathrm{NMR}\left(600 \mathrm{MHz}, \mathrm{DMSO}-\mathrm{d}_{6}\right) \delta=8.35\left(\mathrm{~s}, 1 \mathrm{H}, \mathrm{A}_{2} \mathrm{H}_{8}\right) ; 8.31$ (s, $\left.1 \mathrm{H}, \mathrm{A}_{1} \mathrm{H}_{8}\right) ; 8.16$ (s, $\left.1 \mathrm{H}, \mathrm{A}_{2} \mathrm{H}_{2}\right) ; 8.14\left(\mathrm{~s}, 1 \mathrm{H}, \mathrm{A}_{1} \mathrm{H}_{2}\right) ; 7.42-7.23\left(\mathrm{~m}, 4 \mathrm{H}, \mathrm{A}_{1} \mathrm{NH}_{2}, \mathrm{~A}_{2} \mathrm{NH}_{2}\right) ; 6.08$ (d, $J=4.9 \mathrm{~Hz}, 1 \mathrm{H}, \mathrm{A}_{1} \mathrm{H}_{1}$ ) ; 5.91 (d, $J=5.3 \mathrm{~Hz}, 1 \mathrm{H}, \mathrm{A}_{2} \mathrm{H}_{1^{\prime}}$ ) ; $5.62\left(\mathrm{~d}, J=5.8 \mathrm{~Hz}, 1 \mathrm{H}, \mathrm{A}_{2} \mathrm{OH}_{2^{\prime}}\right) ; 5.49$ (d, $J=5.2 \mathrm{~Hz}, 1 \mathrm{H}, \mathrm{A}_{2} \mathrm{OH}_{3^{\prime}}$ ) ; $5.38\left(\mathrm{~d}, J=5.3 \mathrm{~Hz}, 1 \mathrm{H}, \mathrm{A}_{1} \mathrm{OH}_{3^{\prime}}\right)$; 5.35 (dd, $\left.J=6.5,4.7 \mathrm{~Hz}, 1 \mathrm{H}, \mathrm{A}_{1} \mathrm{OH}_{5^{\prime}}\right) ; 4.90-4.83\left(\mathrm{~m}, 1 \mathrm{H}, \mathrm{A}_{1} \mathrm{H}_{2^{\prime}}\right.$ ) ; $4.75\left(\mathrm{~d}, J=12.6 \mathrm{~Hz}, 1 \mathrm{H}, \mathrm{OCH}_{2} \mathrm{SO}_{2}\right) ; 4.71-4.63\left(\mathrm{~m}, 2 \mathrm{H}, \mathrm{OCH}_{2} \mathrm{SO}_{2}, \mathrm{~A}_{2} \mathrm{H}_{2}\right) ; 4.46-4.40\left(\mathrm{~m}, 1 \mathrm{H}, \mathrm{A}_{1} \mathrm{H}_{3}\right)$ ; 4.28 - $4.23\left(\mathrm{~m}, 1 \mathrm{H}, \mathrm{A}_{2} \mathrm{H}_{4}\right)$ ) $4.21-4.16\left(\mathrm{~m}, 1 \mathrm{H}, \mathrm{A}_{2} \mathrm{H}_{3^{\prime}}\right) ; 3.95-3.89\left(\mathrm{~m}, 1 \mathrm{H}, \mathrm{A}_{1} \mathrm{H}_{4^{\prime}}\right) ; 3.73-3.68(\mathrm{~m}$, $1 \mathrm{H}, \mathrm{A}_{2} \mathrm{H}_{5}$ ) ; $3.68-3.65$ (m, $1 \mathrm{H}, \mathrm{A}_{1} \mathrm{H}_{5}$ ) ; $3.56-3.49$ (m, $1 \mathrm{H}, \mathrm{A}_{1} \mathrm{H}_{5}$ ") ; $3.46-3.39$ (m, $1 \mathrm{H}, \mathrm{A}_{2} \mathrm{H}_{5^{\prime}}$ ). ${ }^{13} \mathrm{C}-$ NMR $\left(150 \mathrm{MHz}, \mathrm{DMSO}-\mathrm{d}_{6}\right) \delta=156.12 \& 156.11\left(\mathrm{~A}_{1} \mathrm{C}_{6} \& \mathrm{~A}_{2} \mathrm{C}_{6}\right) ; 156.69\left(\mathrm{~A}_{2} \mathrm{C}_{2}\right) ; 152.51\left(\mathrm{~A}_{1} \mathrm{C}_{2}\right)$; 149.23 $\left(\mathrm{A}_{2} \mathrm{C}_{4}\right) ; 148.96\left(\mathrm{~A}_{1} \mathrm{C}_{4}\right) ; 139.86\left(\mathrm{~A}_{2} \mathrm{C}_{8}\right) ; 139.52\left(\mathrm{~A}_{1} \mathrm{C}_{8}\right) ; 119.24\left(\mathrm{~A}_{1} \mathrm{C}_{5} \& \mathrm{~A}_{2} \mathrm{C}_{5}\right) ; 88.00\left(\mathrm{~A}_{2} \mathrm{C}_{1}\right)$ ; $86.27\left(\mathrm{~A}_{1} \mathrm{C}_{1^{\prime}}\right)$; $85.51\left(\mathrm{~A}_{1} \mathrm{C}_{4^{\prime}}\right)$; 83.17 \& $83.10\left(\mathrm{~A}_{1} \mathrm{C}_{2}, \& \mathrm{OCH}_{2} \mathrm{SO}_{2}\right) ; 77.76\left(\mathrm{~A}_{2} \mathrm{C}_{4}{ }^{\prime}\right) ; 72.93\left(\mathrm{~A}_{2} \mathrm{C}_{3^{\prime}}\right)$; $72.41\left(\mathrm{~A}_{2} \mathrm{C}_{2}{ }^{\prime}\right) ; 68.88\left(\mathrm{~A}_{1} \mathrm{C}_{3^{\prime}}\right) ; 61.06\left(\mathrm{~A}_{1} \mathrm{C}_{5^{\prime}}\right) ; 52.47\left(\mathrm{~A}_{2} \mathrm{C}_{5^{\prime}}\right)$. HRMS (ESI+): m/z calcd for $\mathrm{C}_{21} \mathrm{H}_{27} \mathrm{~N}_{10} \mathrm{O} 9 \mathrm{~S}:$ 595.1678, found: 595.1675 .

\section{3',5'-bis-O-(tert-butyldimethylsilyl)-2'-O-(2-toluene-sulfonylethyl) adenosine 13}

To a solution of 3',5'-bis-O-(tert-butyldimethylsilyl)-2'-O-(hydroxyethyl) adenosine ${ }^{[23]}$ (1.23 g, 2.34 mmol, $1.00 \mathrm{eq}$ ) in anhydrous $\mathrm{CH}_{2} \mathrm{Cl}_{2}(7 \mathrm{~mL})$ was added successively 4-dimethylaminopyridine $(29 \mathrm{mg}$, $0.23 \mathrm{mmol}, 0.10 \mathrm{eq}), \mathrm{Et}_{3} \mathrm{~N}(0.70 \mathrm{~mL}, 4.92 \mathrm{mmol}, 2.10 \mathrm{eq})$ and 4-toluenesulfonyl chloride (0.893 g, 4.68 mmol, 2.00 eq). After stirring for 4 hours at $0^{\circ} \mathrm{C}$ under argon, the solution was diluted with $\mathrm{CH}_{2} \mathrm{Cl}_{2}$ (30 $\mathrm{mL})$ and washed with saturated aqueous $\mathrm{NaHCO}_{3}$. The aqueous layer was extracted with $\mathrm{CH}_{2} \mathrm{Cl}_{2}(3 \mathrm{x}$ $40 \mathrm{~mL}$ ) and the combined organic extracts were washed with saturated aqueous $\mathrm{NaCl}$ (60 mL), dried over $\mathrm{Na}_{2} \mathrm{SO}_{4}$ and concentrated under vacuum. The residue was purified by chromatography with a linear gradient $0-10 \% \mathrm{MeOH}$ in $\mathrm{CH}_{2} \mathrm{Cl}_{2}$ yielding to 13 as a white solid (1.40 g, $\left.2.02 \mathrm{mmol}, 86 \%\right) . R_{\mathrm{f}} 0.71$ $\left(\mathrm{MeOH} / \mathrm{CH}_{2} \mathrm{Cl}_{2}\right.$ 5:95). ${ }^{1} \mathrm{H}-\mathrm{NMR}\left(500 \mathrm{MHz}, \mathrm{CDCl}_{3}\right) \delta=8.30\left(\mathrm{~s}, 1 \mathrm{H}, \mathrm{H}_{2}\right) ; 8.15\left(\mathrm{~s}, 1 \mathrm{H}, \mathrm{H}_{8}\right) ; 7.75$ (d, J = $\left.8.3 \mathrm{~Hz}, 2 \mathrm{H}, \mathrm{H}_{\text {ortho Ts}}\right) ; 7.29$ (d, J = $\left.8.0 \mathrm{~Hz}, 2 \mathrm{H}, \mathrm{H}_{\text {meta Ts }}\right) ; 6.02$ (d, J = $3.4 \mathrm{~Hz}, 1 \mathrm{H}, \mathrm{H}_{1^{\prime}}$ ); $5.74\left(\mathrm{~s}, 2 \mathrm{H}, \mathrm{NH}_{2}\right)$; 
4.50 (dd, J = 5.7, $\left.4.7 \mathrm{~Hz}, 1 \mathrm{H}, \mathrm{H}_{3}{ }^{\prime}\right)$; 4.31 (dd, $\mathrm{J}=4.7,3.5 \mathrm{~Hz}, 1 \mathrm{H}, \mathrm{H}_{2}$ ) ; $4.20-4.10$ (m, $1 \mathrm{H}, \mathrm{CH}_{2}-\mathrm{O}_{\mathrm{Ts}}$ ) ; 4.04 (m, $1 \mathrm{H}, \mathrm{H}_{4}$ ) ; 3.98 (dd, J = 11.5, $3.4 \mathrm{~Hz}, 1 \mathrm{H}, \mathrm{H}_{5}$ ' or $\mathrm{H}_{5}$ ") ; 3.85 - 3.81 (m, 2H, 2'O-CH $\mathrm{CH}_{2}$; 3.75 (dd, $J=11.5,2.7 \mathrm{~Hz}, 1 \mathrm{H}, \mathrm{H}_{5}$, or $\mathrm{H}_{5}$ ") ; 2.42 (s, $\left.3 \mathrm{H}, \mathrm{CH}_{3} \mathrm{Ts}\right) ; 0.91$ \& 0.89 (2s, $\left.18 \mathrm{H}, \mathrm{Si}-\mathrm{C}_{(}\left(\mathrm{CH}_{3}\right)_{3}\right) ; 0.09-0.06$ $\left(4 \mathrm{~s}, 12 \mathrm{H}, \mathrm{Si}-\mathrm{CH}_{3}\right) .{ }^{13} \mathrm{C}-\mathrm{NMR}\left(125 \mathrm{MHz}, \mathrm{CDCl}_{3}\right) \delta=155.3\left(\mathrm{C}_{6}\right) ; 152.9\left(\mathrm{C}_{2}\right) ; 149.5\left(\mathrm{C}_{4}\right) ; 144.8(\underline{\mathrm{Cq}}-$ $\left.\mathrm{CH}_{3} \mathrm{Ts}\right) ; 139.4\left(\mathrm{C}_{8}\right) ; 132.8\left(\mathrm{Cq}-\mathrm{SO}_{2} C_{\mathrm{Ts}}\right) ; 129.8\left(C_{\text {méta Ts }}\right) ; 128.0\left(C_{\text {ortho Ts }}\right) ; 120.1\left(\mathrm{C}_{5}\right) ; 87.0\left(\mathrm{C}_{1^{\prime}}\right)$; $84.6\left(\mathrm{C}_{4^{\prime}}\right) ; 82.6\left(\mathrm{C}_{2^{\prime}}\right) ; 69.8\left(\mathrm{C}_{3^{\prime}}\right) ; 68.7\left(\mathrm{CH}_{2}-\mathrm{O}_{\mathrm{Ts}}\right) ; 68.3\left(2^{\prime} \mathrm{O}-\mathrm{CH}_{2}\right) ; 61.6\left(\mathrm{C}_{5}\right) ; 26.0$ \& $25.7\left(\mathrm{CH}_{3}\right)_{3}$ твS) ; $21.6\left(\mathrm{CH}_{3 \mathrm{Ts}}\right) ; 18.5 \& 18.1\left(C\left(\mathrm{CH}_{3}\right)_{3} \mathrm{TBS}\right) ;-4.6 \&-4.9 \&-5.4\left(\mathrm{CH}_{3} \mathrm{TBS}\right)$. HRMS (ESI+): m/z calcd for $\mathrm{C}_{31} \mathrm{H}_{52} \mathrm{~N}_{5} \mathrm{O}_{7} \mathrm{SSi}_{2}[\mathrm{M}+\mathrm{H}]^{+}$: 694.3126, found: 694.3121.

\section{3',5'-bis-O-(tert-butyldimethylsilyl)-S-(2'-O-ethyladenosyl)-5'-thioadenosine 14}

To a suspension of 8 (135 mg, $0.42 \mathrm{mmol}, 1.00 \mathrm{eq})$ in $\mathrm{MeOH}(4 \mathrm{~mL})$ was added a solution of $\mathrm{KOH}$ (47 $\mathrm{mg}, 0.83 \mathrm{mmol}, 2.00 \mathrm{eq}$ ) in $\mathrm{MeOH}(2 \mathrm{~mL})$. After stirring for 20 minutes at $0^{\circ} \mathrm{C}$, a solution of 13 (346 $\mathrm{mg}, 0.50 \mathrm{mmol}, 1.20 \mathrm{eq})$ in $\mathrm{CH}_{2} \mathrm{Cl}_{2}(4 \mathrm{~mL})$ was added and the reaction mixture was stirred for additional $2 \mathrm{~h}$ at room temperature. The solvents were removed under vacuum, and the resulting paste was purified by chromatography (dry-load) with a 0-15\% linear gradient $\mathrm{MeOH}$ in $\mathrm{CH}_{2} \mathrm{Cl}_{2}$ yielding to 14 as a white solid (63 mg, $0.078 \mathrm{mmol}, 19 \%) . R_{\mathrm{f}} 0.67\left(\mathrm{MeOH} / \mathrm{CH}_{2} \mathrm{Cl}_{2} 15: 85\right) .{ }^{1} \mathrm{H}-\mathrm{NMR}(400 \mathrm{MHz}$, DMSO-d 6 ) $\delta=$ 8.31 (s, $\left.2 \mathrm{H}, \mathrm{A}_{1} \mathrm{H}_{8} \& \mathrm{~A}_{2} \mathrm{H}_{8}\right)$; 8.14 (s, $\left.1 \mathrm{H}, \mathrm{A}_{\mathrm{x}} \mathrm{H}_{2}\right) ; 8.13\left(\mathrm{~s}, 1 \mathrm{H}, \mathrm{A}_{\mathrm{x}} \mathrm{H}_{2}\right) ; 7.30\left(\mathrm{~s}, 2 \mathrm{H}, \mathrm{A}_{\mathrm{x}} \mathrm{NH}_{2}\right) ; 7.26(\mathrm{~s}, 2 \mathrm{H}$, $\mathrm{A}_{\mathrm{x}} \mathrm{NH}_{2}$ ); 6.01 (d, $\left.J=4.4 \mathrm{~Hz}, 1 \mathrm{H}, \mathrm{A}_{1} \mathrm{H}_{1^{\prime}}\right) ; 5.86\left(\mathrm{~d}, J=5.7 \mathrm{~Hz}, 1 \mathrm{H}, \mathrm{A}_{2} \mathrm{H}_{1^{\prime}}\right) ; 5.48$ (d, $J=6.0 \mathrm{~Hz}, 1 \mathrm{H}$, $\mathrm{A}_{2} \mathrm{OH}_{2^{\prime}}$ ) ; 5.27 (d, $\left.J=5.1 \mathrm{~Hz}, 1 \mathrm{H}, \mathrm{A}_{2} \mathrm{OH}_{3^{\prime}}\right) ; 4.70$ (q, $\left.J=5.7 \mathrm{~Hz}, 1 \mathrm{H}, \mathrm{A}_{2} \mathrm{H}_{2^{\prime}}\right) ; 4.60\left(\mathrm{~m}, 1 \mathrm{H}, \mathrm{A}_{1} \mathrm{H}_{2^{\prime}}\right) ; 4.56$ (m, $1 \mathrm{H}, \mathrm{A}_{1} \mathrm{H}_{3^{\prime}}$ ) ; $4.11-4.07$ (m, $1 \mathrm{H}, \mathrm{A}_{2} \mathrm{H}_{3^{\prime}}$ ) ; 3.97 - 3.86 (m, 3H, $\left.\mathrm{A}_{1} \mathrm{H}_{4}, \mathrm{~A}_{2} \mathrm{H}_{4}, 2^{\prime} \mathrm{OCH}\right)$; 3.70-3.61 (m, 3H, 2'OCH, $\mathrm{A}_{1} \mathrm{H}_{5}, \mathrm{H}_{5}$ ") ; $2.91-2.77$ (m, 2H, $\mathrm{A}_{2} \mathrm{H}_{5}, \mathrm{H}_{5}$ ") ; 2.63 (m, 2H, $\left.\mathrm{CH}_{2} \mathrm{~S}\right) ; 0.87$ (s, 9H, $\left.\mathrm{SiC}\left(\mathrm{CH}_{3}\right)_{3}\right)$ ; 0.83 (s, 9H, $\left.\mathrm{SiC}\left(\mathrm{CH}_{3}\right)_{3}\right) ; 0.09$ (s, 3H, $\left.\mathrm{SiCH}_{3}\right) ; 0.07$ (s, 3H, $\left.\mathrm{SiCH}_{3}\right) ; 0.02$ (s, 3H, $\left.\mathrm{SiCH}_{3}\right) ;-0.00$ (s, 3H, $\left.\mathrm{SiCH}_{3}\right) .{ }^{13} \mathrm{C}-\mathrm{NMR}\left(100 \mathrm{MHz}, \mathrm{DMSO}-\mathrm{d}_{6}\right) \delta=156.0\left(\mathrm{~A}_{\mathrm{x}} \mathrm{C}_{6}\right) ; 152.6\left(\mathrm{~A}_{\mathrm{x}} \mathrm{C}_{2}\right) ; 149.4 \& 149.1\left(\mathrm{~A}_{\mathrm{x}} \mathrm{C}_{4}\right) ; 139.7$ \& $139.3\left(\mathrm{~A}_{\mathrm{x}} \mathrm{C}_{8}\right) ; 119.1\left(\mathrm{~A}_{\mathrm{x}} \mathrm{C}_{5}\right) ; 87.4\left(\mathrm{~A}_{2} \mathrm{C}_{1^{\prime}}\right) ; 85.7\left(\mathrm{~A}_{1} \mathrm{C}_{1^{\prime}}\right) ; 84.3\left(\mathrm{~A}_{1} \mathrm{C}_{4^{\prime}}\right) ; 83.8\left(\mathrm{~A}_{2} \mathrm{C}_{4^{\prime}}\right) ; 80.3\left(\mathrm{~A}_{1} \mathrm{C}_{2^{\prime}}\right)$; $72.6\left(\mathrm{~A}_{2} \mathrm{C}_{2}{ }^{\prime}\right) ; 72.5\left(\mathrm{~A}_{2} \mathrm{C}_{3^{\prime}}\right) ; 69.9\left(\mathrm{~A}_{1} \mathrm{C}_{3^{\prime}}\right) ; 69.7\left(\mathrm{~A}_{1} \mathrm{C}_{5^{\prime}}\right) ; 61.8\left(2^{\prime} \mathrm{OCH}_{2}\right) ; 34.3\left(\mathrm{~A}_{2} \mathrm{C}_{5^{\prime}}\right) ; 31.3\left(\mathrm{CH}_{2} \mathrm{~S}\right)$; -

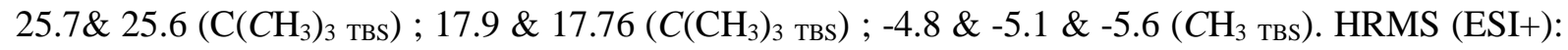
$\mathrm{m} / \mathrm{z}$ calcd for $\mathrm{C}_{34} \mathrm{H}_{57} \mathrm{~N}_{10} \mathrm{O}_{7} \mathrm{SSi}_{2}[\mathrm{M}+\mathrm{H}]^{+}:$: 805.3671, found: 805.3669 .

\section{S-(2'-O-ethyladenosyl)-5'-thioadenosine 4}

To a solution of 14 (63 mg, $0.078 \mathrm{mmol}, 1.00 \mathrm{eq})$ in anhydrous THF $(3.7 \mathrm{~mL})$ was added $1 \mathrm{M} \mathrm{Et}{ }_{3} \mathrm{~N}-3 \mathrm{HF}$ solution in THF ( $50 \mu \mathrm{L}, 0.31 \mathrm{mmol}, 4.00 \mathrm{eq})$. After stirring for $3 \mathrm{~h}$ at $50^{\circ} \mathrm{C}$, the reaction mixture was treated with $2 \mathrm{M}$ triethylammonium acetate buffer $(\mathrm{pH} 7)$. The solvents were removed under vacuum before water $(10 \mathrm{~mL})$ and $\mathrm{CH}_{2} \mathrm{Cl}_{2}(10 \mathrm{~mL})$ were added. The aqueous layer was extracted three times with $\mathrm{CH}_{2} \mathrm{Cl}_{2}$ and once with $\mathrm{Et}_{2} \mathrm{O}$. The solvent was removed under vacuum and the resulting paste was purified by chromatography on a reversed-phase $\mathrm{C}_{18}$ silica gel column $(4 \mathrm{~g}, 40 \mu \mathrm{m})$ with a $0-25 \%$ linear gradient of acetonitrile in $50 \mathrm{mM}$ TEAAc buffer, $\mathrm{pH} 7$ followed by concentration and lyophilization of pure fractions to give 4 as a white powder (20 mg, $0.035 \mathrm{mmol}$, 44\%) with 99\% purity determined by HPLC analysis at $260 \mathrm{~nm} .{ }^{1} \mathrm{H}-\mathrm{NMR}\left(600 \mathrm{MHz}, \mathrm{DMSO}-\mathrm{d}_{6}\right) \delta=8.37$ (s, $\left.1 \mathrm{H}, \mathrm{A}_{1} \mathrm{H}_{8}\right) ; 8.33\left(\mathrm{~s}, 1 \mathrm{H}, \mathrm{A}_{2} \mathrm{H}_{8}\right) ; 8.14$ (2s, $2 \mathrm{H}, \mathrm{A}_{1} \mathrm{H}_{2} \& \mathrm{~A}_{2} \mathrm{H}_{2}$ ) ; 7.34 \& 7.28 (2 br s, $4 \mathrm{H}, \mathrm{A}_{1} \mathrm{NH}_{2} \& \mathrm{~A}_{2} \mathrm{NH}_{2}$ ); 6.00 (d, $J=5.9 \mathrm{~Hz}, 1 \mathrm{H}, \mathrm{A}_{1} \mathrm{H}_{1^{\prime}}$ ) ; 5.87 (d, $J=5.7 \mathrm{~Hz}, 1 \mathrm{H}, \mathrm{A}_{2} \mathrm{H}_{1}$ ) ; 5.49 (d, $J=6.1 \mathrm{~Hz}, 1 \mathrm{H}, \mathrm{A}_{2} \mathrm{OH}_{2}$ ) ; 5.38 (dd, $J=6.9,4.8 \mathrm{~Hz}, 1 \mathrm{H}$, $\left.\mathrm{A}_{1} \mathrm{OH}_{5^{\prime}}\right) ; 5.29\left(\mathrm{~d}, J=5.1 \mathrm{~Hz}, 1 \mathrm{H}, \mathrm{A}_{2} \mathrm{OH}_{3^{\prime}}\right) ; 5.17\left(\mathrm{~d}, J=5.2 \mathrm{~Hz}, 1 \mathrm{H}, \mathrm{A}_{1} \mathrm{OH}_{3^{\prime}}\right) ; 4.71(\mathrm{q}, J=5.6 \mathrm{~Hz}, 1 \mathrm{H}$, $\left.\mathrm{A}_{2} \mathrm{H}_{2^{\prime}}\right) ; 4.50\left(\mathrm{~m}, 1 \mathrm{H}, \mathrm{A}_{1} \mathrm{H}_{2^{\prime}}\right) ; 4.32\left(\mathrm{~m}, 1 \mathrm{H}, \mathrm{A}_{1} \mathrm{H}_{3^{\prime}}\right) ; 4.10\left(\mathrm{~m}, 1 \mathrm{H}, \mathrm{A}_{2} \mathrm{H}_{3^{\prime}}\right) ; 3.98\left(\mathrm{~m}, 2 \mathrm{H}, \mathrm{A}_{1} \mathrm{H}_{4^{\prime}}\right.$ \& $\left.\mathrm{A}_{2} \mathrm{H}_{4^{\prime}}\right)$; 3.72 - 3.65, 3.55 - 3.52 (m, 4H, $\mathrm{A}_{1} \mathrm{H}_{5}, \mathrm{~A}_{1} \mathrm{H}_{5}$,, $\left.2^{\prime} \mathrm{OCH}_{2}\right) ; 2.90-2.79$ (m, $2 \mathrm{H}, \mathrm{A}_{2} \mathrm{H}_{5}, \mathrm{~A}_{2} \mathrm{H}_{5}$ ") ; 2.65 (m, $\left.2 \mathrm{H}, \mathrm{CH}_{2} \mathrm{~S}\right) .{ }^{13} \mathrm{C}-\mathrm{NMR}\left(150 \mathrm{MHz}, \mathrm{DMSO}-\mathrm{d}_{6}\right) \delta=156.14 \& 156.05\left(\mathrm{~A}_{1} \mathrm{C}_{6} \& \mathrm{~A}_{2} \mathrm{C}_{6}\right) ; 152.65 \& 152.52$ $\left(\mathrm{A}_{1} \mathrm{C}_{2} \& \mathrm{~A}_{2} \mathrm{C}_{2}\right) ; 149.5\left(\mathrm{~A}_{2} \mathrm{C}_{4}\right) ; 149.0\left(\mathrm{~A}_{1} \mathrm{C}_{4}\right) ; 139.74\left(\mathrm{~A}_{2} \mathrm{C}_{8}\right) ; 139.66\left(\mathrm{~A}_{1} \mathrm{C}_{8}\right) ; 119.3\left(\mathrm{~A}_{1} \mathrm{C}_{5}\right) ; 119.1$ $\left(\mathrm{A}_{2} \mathrm{C}_{5}\right) ; 87.2\left(\mathrm{~A}_{2} \mathrm{C}_{1^{\prime}}\right) ; 86.1\left(\mathrm{~A}_{1} \mathrm{C}_{4^{\prime}}\right) ; 86.0\left(\mathrm{~A}_{1} \mathrm{C}_{1^{\prime}}\right) ; 83.8\left(\mathrm{~A}_{2} \mathrm{C}_{4^{\prime}}\right) ; 81.0\left(\mathrm{~A}_{1} \mathrm{C}_{2}\right) ; 72.6\left(\mathrm{~A}_{2} \mathrm{C}_{2}{ }^{\prime}\right) ; 72.5$ 
$\left(\mathrm{A}_{2} \mathrm{C}_{3^{\prime}}\right)$; $69.5\left(\mathrm{~A}_{1} \mathrm{C}_{5}\right.$, or $\left.{ }^{\prime}{ }^{\prime} \mathrm{OCH}_{2}\right)$; $68.9\left(\mathrm{~A}_{1} \mathrm{C}_{3^{\prime}}\right) ; 61.3\left(\mathrm{~A}_{1} \mathrm{C}_{5}\right.$, or $\left.2^{\prime} \mathrm{OCH}_{2}\right)$; $34.2\left(\mathrm{~A}_{2} \mathrm{C}_{5}{ }^{\prime}\right) ; 31.2\left(\mathrm{CH}_{2} \mathrm{~S}\right)$. HRMS (ESI+): $\mathrm{m} / \mathrm{z}$ calcd for $\mathrm{C}_{22} \mathrm{H}_{29} \mathrm{~N}_{10} \mathrm{O}_{7} \mathrm{~S}[\mathrm{M}+\mathrm{H}]^{+}$: 577.1933, found: 577.1933.

\section{S-(5'-O-(4,4'-dimethoxytrityl-2'-O-methylthioadenosyl)-5'-thioadenosine 19}

To a solution of $\mathbf{1 7}^{[21]}$ (202 $\left.\mathrm{mg}, 0.26 \mathrm{mmol}, 1.00 \mathrm{eq}\right)$ in $\mathrm{MeOH}$ (3.5 mL) was added $\mathbf{1 8}^{\text {[22a] }}$ (200 mg, 0.46 mmol, $1.80 \mathrm{eq})$ and an ammonia solution $(7 \mathrm{M}$ in $\mathrm{MeOH})(7.5 \mathrm{~mL})$. After stirring for $20 \mathrm{~min}$ at $-10^{\circ} \mathrm{C}$ under argon, the solvents were removed and the resulting residue was purified by chromatography (dryload) on reversed-phase silica gel column $\mathrm{C}_{18}$ with a $20-70 \%$ linear gradient of acetonitrile in $50 \mathrm{mM}$ TEAAc buffer, $\mathrm{pH}$ 7. The fractions containing 19 with more than $75 \%$ purity were pooled and concentrated to dryness. Traces of TEAAc salts were removed by several coevaporations with water and acetonitrile to give compound 19 (92 mg, $0.102 \mathrm{mmol}$, 40\% corrected yield) with 75\% purity determined by HPLC analysis at $260 \mathrm{~nm}$. The main contaminant was the 5'-O-DMTr adenosine. Full characterization of 19 was performed with a $99 \%$ pure fraction isolated after purification. ${ }^{1} \mathrm{H}-\mathrm{NMR}$ (400 MHz, 1,4-Dioxane- $\left.\mathrm{d}_{8}\right) \delta=8.16$ (s, $1 \mathrm{H}, \mathrm{H}_{2}$ or $\mathrm{H}_{8}$ ) ; 8.14 (s, $1 \mathrm{H}, \mathrm{H}_{2}$ or $\left.\mathrm{H}_{8}\right)$; 8.01 (s, $1 \mathrm{H}, \mathrm{H}_{2}$ or $\mathrm{H}_{8}$ ) ; 7.95 (s, $1 \mathrm{H}, \mathrm{H}_{2}$ or $\mathrm{H}_{8}$ ) ; $7.43-7.13$ (m, 9H, $\mathrm{H}_{\text {DMTR }}$ ) 6.78 (m, 4H, $\mathrm{H}_{\text {DMTR }}$ ) 6.47 (br s, 4H, $\mathrm{NH}_{2}$ ) ; 6.15 (d, $J=3.7 \mathrm{~Hz}, 1 \mathrm{H}, \mathrm{A}_{1} \mathrm{H}_{1}$ ) ; 5.84 (d, $J=4.4 \mathrm{~Hz}, 1 \mathrm{H}, \mathrm{A}_{2} \mathrm{H}_{1}$ ) ; $5.05\left(\mathrm{~m}, 2 \mathrm{H}, \mathrm{O}-\mathrm{CH}_{2}-\mathrm{S}\right) ; 4.93(\mathrm{~m}, 1 \mathrm{H}$, $\left.\mathrm{A}_{1} \mathrm{H}_{2^{\prime}}\right) ; 4.82-4.66\left(\mathrm{~m}, 2 \mathrm{H}, \mathrm{A}_{2} \mathrm{OH}_{3^{\prime}}, \mathrm{A}_{2} \mathrm{H}_{2^{\prime}}\right) ; 4.49\left(\mathrm{~d}, 1 \mathrm{H}, \mathrm{A}_{1} \mathrm{H}_{3^{\prime}}\right) ; 4.42-4.34\left(\mathrm{~m}, 1 \mathrm{H}, \mathrm{A}_{2} \mathrm{OH}_{2^{\prime}}\right) ; 4.29$ (m, $\left.1 \mathrm{H}, \mathrm{A}_{2} \mathrm{H}_{3^{\prime}}\right) ; 4.23-4.16\left(\mathrm{~m}, 1 \mathrm{H}, \mathrm{A}_{2} \mathrm{H}_{4^{\prime}}\right) ; 4.16-4.11\left(\mathrm{~m}, 1 \mathrm{H}, \mathrm{A}_{1} \mathrm{H}_{4^{\prime}}\right) ; 4.03(\mathrm{~d}, J=7.2 \mathrm{~Hz}, 1 \mathrm{H}$, $\mathrm{A}_{1} \mathrm{OH}_{3^{\prime}}$ ) ; 3.73 (s, $6 \mathrm{H}, \mathrm{OCH}_{3 \text { DMTR }}$ ) ; $3.42-3.37$ (m, $2 \mathrm{H}, \mathrm{A}_{1} \mathrm{H}_{5}, \mathrm{H}_{5}$ ) ; 3.08 (d, $J=6.3 \mathrm{~Hz}, 2 \mathrm{H}, \mathrm{A}_{2} \mathrm{H}_{5}, \mathrm{H}_{5^{\prime \prime}}$ ). ${ }^{13} \mathrm{C}-\mathrm{NMR}\left(150 \mathrm{MHz}, 1,4-\mathrm{Dioxane}-\mathrm{d}_{8}\right) \delta=159.5\left(\mathrm{Cq}-\mathrm{OCH}_{3}\right.$ DMTR $) ; 157.0$ et $157.1\left(\mathrm{~A}_{1} \mathrm{C}_{5}\right.$ et $\left.\mathrm{A}_{2} \mathrm{C}_{5}\right) ; 153.7$ et $153.9\left(\mathrm{~A}_{1} \mathrm{C}_{6}\right.$ et $\left.\mathrm{A}_{2} \mathrm{C}_{6}\right) ; 150.3\left(\mathrm{~A}_{1} \mathrm{C}_{4}\right.$ et $\left.\mathrm{A}_{2} \mathrm{C}_{4}\right) ; 146.1$ (Cq DMTR); 140.2 et $140.6\left(\mathrm{~A}_{1} \mathrm{C}_{8}\right.$ et $\left.\mathrm{A}_{2} \mathrm{C}_{8}\right) ; 136.8$ (Cq DMTR $) ; 127.5,128.5,129.0,130.9\left(C_{\text {DMTR }}\right) ; 120.8$ et $120.9\left(\mathrm{~A}_{1} \mathrm{C}_{2}\right.$ et $\left.\mathrm{A}_{2} \mathrm{C}_{2}\right) ; 113.9\left(C \mathrm{CH}_{\text {DMTR }}\right) ; 90.3$ $\left(\mathrm{A}_{1} \mathrm{C}_{1^{\prime}}\right) ; 87.7\left(\mathrm{~A}_{2} \mathrm{C}_{1^{\prime}}\right)$; $87.1\left(\mathrm{O}-\mathrm{Cq}_{\text {DMTR }}\right) ; 84.4\left(\mathrm{~A}_{1} \mathrm{C}_{4^{\prime}}\right)$; $83.6\left(\mathrm{~A}_{2} \mathrm{C}_{4^{\prime}}\right) ; 81.2\left(\mathrm{O}-\mathrm{CH}_{2}-\mathrm{S}\right) ; 80.5\left(\mathrm{~A}_{1} \mathrm{C}_{2^{\prime}}\right)$; $74.5\left(\mathrm{~A}_{2} \mathrm{C}_{2}{ }^{\prime}\right) ; 73.8\left(\mathrm{~A}_{2} \mathrm{C}_{3^{\prime}}\right) ; 70.7\left(\mathrm{~A}_{1} \mathrm{C}_{3^{\prime}}\right) ; 64.2\left(\mathrm{~A}_{1} \mathrm{C}_{5^{\prime}}\right) ; 55.3\left(\mathrm{O}^{\prime} \mathrm{CH}_{3}\right) ; 42.8\left(\mathrm{~A}_{2} \mathrm{C}_{5^{\prime}}\right)$. HRMS (ESI $): \mathrm{m} / \mathrm{z}$ calcd for $\mathrm{C}_{42} \mathrm{H}_{43} \mathrm{~N}_{10} \mathrm{O}_{9} \mathrm{~S}_{2}$ [M-H]-: 895.2661, found: 895.2679.

\section{S-(2'-O-methylthioadenosyl)-5'-thioadenosine 5}

The mixture of 19 and the by-product 5'-O-DMTr adenosine was treated with a solution of $80 \%$ acetic acid in water $(8.76 \mathrm{~mL})$ and stirred for $15 \mathrm{~min}$ at room temperature. The mixture solution was washed with $\mathrm{CHCl}_{3}(10 \times 5 \mathrm{~mL})$ then $\mathrm{Et}_{2} \mathrm{O}(1 \times 10 \mathrm{~mL})$. The solvent was removed under vacuum and the resulting residue was purified by chromatography on a reversed-phase silica gel column $\mathrm{C}_{18}$ ( $4 \mathrm{~g}, 40$ $\mu \mathrm{m}$ ) with a $0-25 \%$ linear gradient of acetonitrile in TEAAc buffer $50 \mathrm{mM}$, $\mathrm{pH} 7$. The fractions containing the pure compound was pooled, concentrated and lyophilized to give 5 as a white powder (23 mg, 38.6 $\mu$ mol, $15 \%$ over two steps) with 99\% purity determined by HPLC analysis at $260 \mathrm{~nm} .{ }^{1} \mathrm{H}-\mathrm{NMR}$ (400 $\mathrm{MHz}, 1,4-$ Dioxane- $\left.\mathrm{d}_{8}\right) \delta=8.19\left(\mathrm{~s}, 1 \mathrm{H}, \mathrm{A}_{1} \mathrm{H}_{2}\right) ; 8.18\left(\mathrm{~s}, 1 \mathrm{H}, \mathrm{A}_{2} \mathrm{H}_{2}\right) ; 7.98\left(\mathrm{~s}, 1 \mathrm{H}, \mathrm{A}_{1} \mathrm{H}_{8}\right) ; 7.97(\mathrm{~s}, 1 \mathrm{H}$, $\mathrm{A}_{2} \mathrm{H}_{8}$ ) ; 6.62 (br s, $2 \mathrm{H}, \mathrm{NH}_{2}$ ) ; 6.50 (br s, $\left.2 \mathrm{H}, \mathrm{NH}_{2}\right) ; 6.00-5.95$ (m, $2 \mathrm{H}, \mathrm{A}_{1} \mathrm{H}_{1}, \mathrm{~A}_{1} \mathrm{OH}_{5}$ ) ; 5.86 (d, $J=4.3$ $\mathrm{Hz}, \mathrm{A}_{2} \mathrm{H}_{1^{\prime}}$ ) ; 4.99 (m, $\left.1 \mathrm{H}, \mathrm{A}_{1} \mathrm{H}_{2^{\prime}}\right) ; 4.82$ (s, $\left.2 \mathrm{H}, \mathrm{OCH}_{2} \mathrm{~S}\right) ; 4.80$ (m, $2 \mathrm{H}, \mathrm{A}_{2} \mathrm{H}_{2^{\prime}}, \mathrm{A}_{2} \mathrm{OH}_{2^{\prime}}$ ) ; 4.44 (m, $2 \mathrm{H}$, $\left.\mathrm{A}_{2} \mathrm{OH}_{3}, \mathrm{~A}_{2} \mathrm{H}_{3^{\prime}}\right) ; 4.30\left(\mathrm{~m}, 1 \mathrm{H}, \mathrm{A}_{2} \mathrm{H}_{3^{\prime}}\right) ; 4.12\left(\mathrm{~m}, 2 \mathrm{H}, \mathrm{A}_{1} \mathrm{H}_{4^{\prime}}, \mathrm{A}_{2} \mathrm{H}_{4}{ }^{\prime}\right) ; 3.99$ (d, $J=4.2 \mathrm{~Hz}, \mathrm{~A}_{1} \mathrm{OH}_{3^{\prime}}$ ) ; 3.843.59 (m, 2H, $\mathrm{A}_{1} \mathrm{H}_{5}, \mathrm{~A}_{1} \mathrm{H}_{5}$ ") ; 3.00 (dd, $\left.J=1.7 \mathrm{~Hz}, J=5.9 \mathrm{~Hz}, 2 \mathrm{H}, \mathrm{A}_{2} \mathrm{H}_{5}, \mathrm{~A}_{2} \mathrm{H}_{5}{ }^{\prime}\right) .{ }^{13} \mathrm{C}-\mathrm{NMR}(125 \mathrm{MHz}$, 1,4-Dioxane-d $\left.\mathrm{d}_{8}\right) \delta=157.5\left(\mathrm{~A}_{1} \mathrm{C}_{6}\right) ; 157.2\left(\mathrm{~A}_{2} \mathrm{C}_{6}\right) ; 153.7\left(\mathrm{~A}_{1} \mathrm{C}_{2}\right) ; 153.7\left(\mathrm{~A}_{1} \mathrm{C}_{2}\right) ; 153.4\left(\mathrm{~A}_{2} \mathrm{C}_{2}\right) ; 150.3$ $\left(\mathrm{A}_{1} \mathrm{C}_{4}\right) ; 149.6\left(\mathrm{~A}_{2} \mathrm{C}_{4}\right) ; 141.4\left(\mathrm{~A}_{1} \mathrm{C}_{8}\right) ; 140.7\left(\mathrm{~A}_{2} \mathrm{C}_{8}\right) ; 121.7\left(\mathrm{~A}_{1} \mathrm{C}_{5}\right) ; 121.1\left(\mathrm{~A}_{2} \mathrm{C}_{5}\right) ; 90.4\left(\mathrm{~A}_{2} \mathrm{C}_{1}\right) ; 89.2$ $\left(\mathrm{A}_{1} \mathrm{C}_{1^{\prime}}\right) ; 88.6\left(\mathrm{~A}_{1} \mathrm{C}_{4}\right) ; 83.5\left(\mathrm{~A}_{2} \mathrm{C}_{4}\right) ; 81.2\left(\mathrm{~A}_{1} \mathrm{C}_{2}\right)$; $81.1\left(\mathrm{OCH}_{2} \mathrm{~S}\right) ; 74.5\left(\mathrm{~A}_{2} \mathrm{C}_{2}\right) ; 73.9\left(\mathrm{~A}_{2} \mathrm{C}_{3^{\prime}}\right) ; 71.2$ $\left(\mathrm{A}_{1} \mathrm{C}_{3^{\prime}}\right) ; 63.3\left(\mathrm{~A}_{1} \mathrm{C}_{5}\right)$; $42.8\left(\mathrm{~A}_{2} \mathrm{C}_{5}\right)$. HRMS (ESI + ): $\mathrm{m} / \mathrm{z}$ calcd for $\mathrm{C}_{21} \mathrm{H}_{27} \mathrm{~N}_{10} \mathrm{O}_{7} \mathrm{~S}_{2}[\mathrm{M}+\mathrm{H}]^{+}:$595.1506, found: 595.1505 .

\section{Acknowledgments}


Rostom Ahmed-Belkacem thanks the University of Montpellier for financial support.

\section{Keywords}

Bisubstrate; RNA 2'-O-methylation; transition states; viral RNA methyltransferases; Nucleosides

\section{References}

[1] W.-S. Ryu, in Molecular Virology of Human Pathogenic Viruses (Ed.: W.-S. Ryu), Academic Press, Boston, 2017, pp. 289-302.

[2] a) D. W. Leung, G. K. Amarasinghe, Curr. Opin. Struct. Biol. 2016, 36, 133-141; b) E. Decroly, B. Canard, Curr. Opin. Virol. 2017, 24, 87-96; c) M. Ringeard, V. Marchand, E. Decroly, Y. Motorin, Y. Bennasser, Nature 2019, 565, 500-504.

[3] E. Decroly, F. Ferron, J. Lescar, B. Canard, Nat. Rev. Microbiol. 2011, 10, 51-65.

[4] a) B. Martin, B. Coutard, T. Guez, G. C. Paesen, B. Canard, F. Debart, J.-J. Vasseur, J. M. Grimes, E. Decroly, Nucleic Acids Res. 2018, 46, 7902-7912; b) B. Coutard, K. Barral, J. Lichiere, B. Selisko, B. Martin, W. Aouadi, M. O. Lombardia, F. Debart, J. J. Vasseur, J. C. Guillemot, B. Canard, E. Decroly, J. Virol. 2017, 91, e02202-02216; c) H. Dong, D. C. Chang, M. H. Hua, S. P. Lim, Y. H. Chionh, F. Hia, Y. H. Lee, P. Kukkaro, S. M. Lok, P. C. Dedon, P. Y. Shi, PloS Pathog. 2012, 8, e1002642.

[5] a) R. Zust, L. Cervantes-Barragan, M. Habjan, R. Maier, B. W. Neuman, J. Ziebuhr, K. J. Szretter, S. C. Baker, W. Barchet, M. S. Diamond, S. G. Siddell, B. Ludewig, V. Thiel, Nat. Immunol. 2011, 12, 137-143; b) S. C. Devarkar, C. Wang, M. T. Miller, A. Ramanathan, F. Jiang, A. G. Khan, S. S. Patel, J. Marcotrigiano, Proc. Natl. Acad. Sci. U S A 2016, 113, 596601.

[6] a) S. Daffis, K. J. Szretter, J. Schriewer, J. Li, S. Youn, J. Errett, T. Y. Lin, S. Schneller, R. Zust, H. Dong, V. Thiel, G. C. Sen, V. Fensterl, W. B. Klimstra, T. C. Pierson, R. M. Buller, M. Gale, Jr., P. Y. Shi, M. S. Diamond, Nature 2010, 468, 452-456; b) P. Kumar, T. R. Sweeney, M. A. Skabkin, O. V. Skabkina, C. U. Hellen, T. V. Pestova, Nucleic Acids Res. 2014, 42, 3228-3245.

[7] J. Zhang, Y. G. Zheng, ACS Chem. Biol. 2016, 11, 583-597.

[8] L. Halby, Y. Menon, E. Rilova, D. Pechalrieu, V. Masson, C. Faux, M. A. Bouhlel, M.-H. David-Cordonnier, N. Novosad, Y. Aussagues, A. Samson, L. Lacroix, F. Ausseil, L. Fleury, D. Guianvarc'h, C. Ferroud, P. B. Arimondo, J. Med. Chem. 2017, 60, 4665-4679.

[9] a) B. Masjost, P. Ballmer, E. Borroni, G. Zürcher, F. K. Winkler, R. Jakob-Roetne, F. Diederich, Chem. Eur. J. 2000, 6, 971-982; b) C. Lerner, B. Masjost, A. Ruf, V. Gramlich, R. JakobRoetne, G. Zürcher, E. Borroni, F. Diederich, Org. Biomol. Chem. 2003, 1, $42-49$.

[10] a) J. Dowden, W. Hong, R. V. Parry, R. A. Pike, S. G. Ward, Bioorg. Med. Chem. Lett. 2010, 20, 2103-2105; b) M. van Haren, L. Q. van Ufford, E. E. Moret, N. I. Martin, Org. Biomol. Chem. 2015, 13, 549-560.

[11] N. Babault, A. Allali-Hassani, F. Li, J. Fan, A. Yue, K. Ju, F. Liu, M. Vedadi, J. Liu, J. Jin, J. Med. Chem. 2018, 61, 1541-1551.

[12] L. Halby, N. Marechal, D. Pechalrieu, V. Cura, D.-M. Franchini, C. Faux, F. Alby, N. TrofferCharlier, S. Kudithipudi, A. Jeltsch, W. Aouadi, E. Decroly, J.-C. Guillemot, P. Page, C. Ferroud, L. Bonnefond, D. Guianvarc'h, J. Cavarelli, P. B. Arimondo, Phil. Trans. R. Soc. B 2018, 373, 20170072.

[13] E. Benghiat, P. A. Crooks, R. Goodwin, F. Rottman, J. Pharm. Sci. 1986, 75, 142-145.

[14] C. Atdjian, L. Iannazzo, E. Braud, M. Ethève-Quelquejeu, Eur. J. Org. Chem. 2018, 2018, 44114425.

[15] S. Oerum, M. Catala, C. Atdjian, F. Brachet, L. Ponchon, P. Barraud, L. Iannazzo, L. Droogmans, E. Braud, M. Ethève-Quelquejeu, C. Tisné, RNA Biology 2019, 1-11.

[16] a) S. H. Kawai, D. Wang, P. A. Giannaris, M. J. Damha, G. Just, Nucleic Acids Res. 1993, 21, 1473-1479; b) B. Meng, S. H. Kawai, D. Wang, G. Just, P. A. Giannaris, M. J. Damha, Angew. Chem. Int. Ed. 1993, 32, 729-731; c) M. J. Damha, B. Meng, D. G. Wang, C. G. Yannopoulos, G. Just, Nucleic Acids Res. 1995, 23, 3967-3973. 
[17] F. Gao, X. Yan, O. Zahr, A. Larsen, K. Vong, K. Auclair, Bioorg. Med. Chem. Lett. 2008, 18, $5518-5522$.

[18] D. Mandalapu, X. Ji, Q. Zhang, Biochemistry 2019, 58, 36-39.

[19] a) B. Musicki, T. S. Widlanski, Tetrahedron Lett. 1991, 32, 1267-1270; b) D. G. Wang, B. Meng, M. J. Damha, G. Just, Nucleosides \& Nucleotides 1995, 14, 1961-1984.

[20] R. Petrelli, Y. Y. Sham, L. Chen, K. Felczak, E. Bennett, D. Wilson, C. Aldrich, J. S. Yu, L. Cappellacci, P. Franchetti, M. Grifantini, F. Mazzola, M. Di Stefano, G. Magni, K. W. Pankiewicz, Bioorg. Med. Chem. 2009, 17, 5656-5664.

[21] F. Gauthier, F. Beltran, A. Biscans, F. Debart, C. Dupouy, J.-J. Vasseur, Org. Biomol. Chem. 2018, 16, 3181-3188.

[22] a) M. Pignot, G. Pljevaljcic, E. Weinhold, Eur. J. Org. Chem. 2000, 2000, 549-555; b) G. Guillerm, D. Guillerm, C. Vandenplas-Vitkowski, C. Glapski, E. De Clercq, Bioorg. Med. Chem. Lett. 2003, 13, 1649-1652.

[23] S. Jin, C. V. Miduturu, D. C. McKinney, S. K. Silverman, J. Org. Chem. 2005, 70, 4284-4299.

[24] C. Dalhoff, M. Hüben, T. Lenz, P. Poot, E. Nordhoff, H. Köster, E. Weinhold, ChemBioChem 2010, 11, 256-265. 
A nucleosidic bisubstrate approach is developed to target 2'-O-RNA methyltransferases that catalyse the methylation of the 2'-OH of the cap nucleoside $\mathrm{N} 1$ or internal adenosines of RNA substrate using $S$-adenosyl methionine as the methyl donor. Bisubstrate analogues have been designed as a mimic of the transition state of the 2'-O-methylation on RNA with two adenosines connected by various sulphur atom-containing linkers.

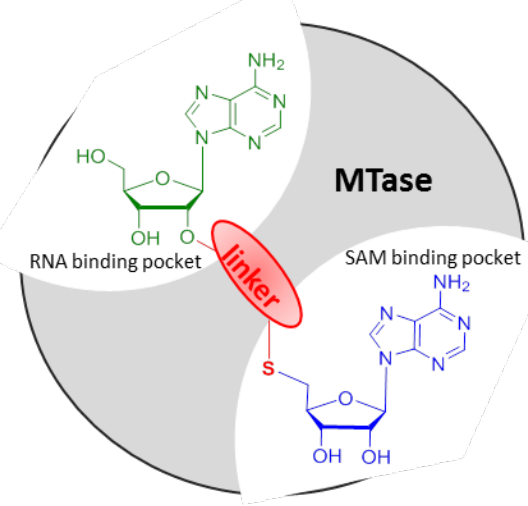

RNA methyltransferases

Rostom Ahmed-Belkacem, ${ }^{1}$ Priscila Sutto Ortiz, ${ }^{2}$ Etienne Decroly, ${ }^{2}$ JeanJacques Vasseur ${ }^{1}$ and Françoise Debart $^{1, *}$

Page No. - Page No.

Synthesis of adenine dinucleosides 2',5'-bridged by sulfur-containing linkers as bisubstrate SAM analogues for viral RNA 2'-O-methyltransferases 